\title{
LA CARTA FICTICIA GRIEGA: LOS NOMBRES DE PERSONAJES Y EL USO DEL ENCABEZAMIENTO EN ALCIFRÓN, ARISTÉNETO Y TEOFILACTO
}

The "mimetic" fictitious letter is related closely to the ethopoeia (a preparatory rethoric exercice consisting of reproducing the words of a character in a given situation). The paper even shows that some of the mimetic letters included in the corpora of Alciphro, Aristaenetus and Theophylactus are true ethopoeiae. We also study the headings of the letters as well as the proper names of characters.

1. El presente trabajo ${ }^{1}$ se ocupa de la carta ficticia e indaga sobre su naturaleza como género. Para ello hemos analizado los textos correspondientes de Alcifrón, Eliano, Filóstrato, Aristéneto, Teofilacto y Ovidio. En bastantes ocasiones dichos textos nos hicieron sospechar de una naturaleza epistolar que la transmisión manuscrita ha consagrado. Además, presentamos los resultados del estudio de los nombres de personaje ficticio empleados por los epistológrafos, constatando las diferencias que existen entre los nombres aparecidos en el cuerpo de carta y aquellos que sirven de encabezamiento a las cartas.

2. La carta ficticia se halla estrechamente vinculada a la $\eta \theta 0 n o i t a^{2}$,

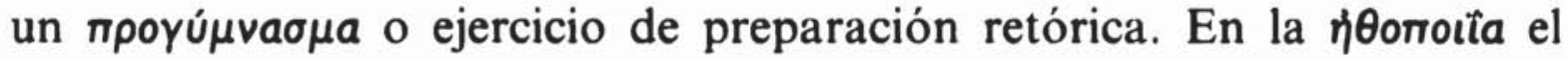

' La idea y parte del mismo, proceden del interés que en nosotros despertó Alcifrón durante la realización de nuestra Tesis Doctoral, dirigida por el Dr. D. José Antenio Fernández Delgado y titulada El diálogo de Luciano: ejecución, naturaleza, composición y procedimientos de humor, Univ. de Extremadura 1991 (inédita). Comparábamos el uso que Luciano y Alcifrón hacian de los nombres propios de personaje ficticio, y a través de esa comparación llegamos a conclusiones que creimos oportuno incluir en un excursus de la Tesis, titulado "Nombres de personajes ficticios en Alcifrón". A lo allí tratado añadimos ahora los resultados del estudio de las cartas de Eliano, Filóstrato, Aristéneto, Teofilacto y las Heroidas de Ovidio. Agradecemos las valiosas sugerencias de los Profs. D. J. A. Fernández Delgado, D. F. L. Lisi Bereterbide, D. F. Cortés Gabaudan y D. G. Laguna Mariscal, que leyeron el artículo en una última versión.

${ }^{2}$ Sobre este aspecto, véase I. Sykutris, "Epistolographie», RE Suppl. V, cols. 194-195 y 215-216; Sykutris titula el apartado donde trata este tipo de cartas «Der 
autor trata de exponer el $\eta \theta 0 \varsigma$ del personaje que habla y también de la persona a la que se dirige ${ }^{3}$; en la carta el $\eta \hat{\theta} 0$ os del remitente o del destinatario ${ }^{4}$. Otro punto de contacto entre ambas es, según Nicolao, el hecho de que sirven para elogiar, acusar o aconsejar ${ }^{5}$. Por su parte, el

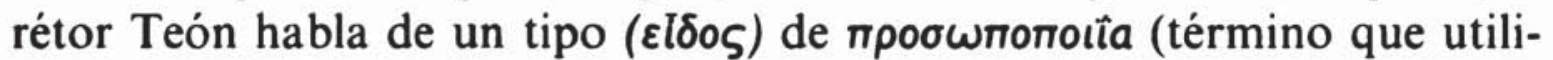

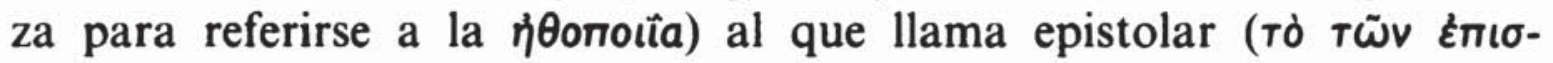

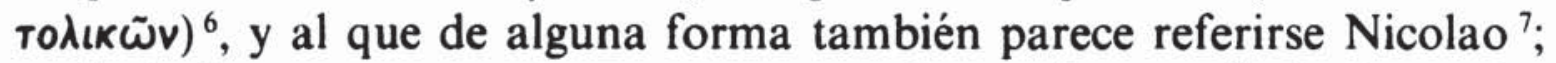
es decir, la etopeya puede presentarse en forma de carta ${ }^{8}$. Ambas, además, son equiparadas al diálogo. Teón dice de la etopeya que es un

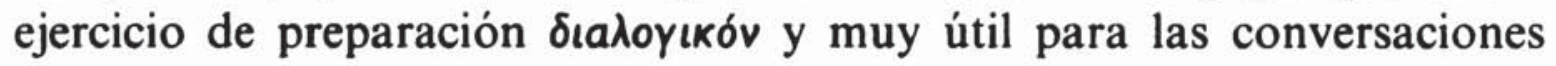

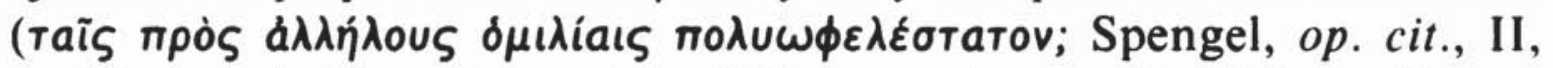
p. 60). La relación entre carta y diálogo puede verse también en Deme-

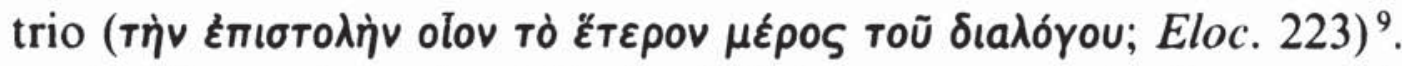

3. La carta - también la ficticia - es un acto de comunicación. Existen, por tanto, un emisor, un receptor y un mensaje. Los nombres del emisor y receptor (del remitente y destinatario), es decir, del «yo»/ «nosotros» y del «tú»/«vosotros», son anticipados en la mayoría de las composiciones que ahora estudiamos en el encabezamiento de carta; el

mimische Brief". Sobre el posible aporte de los ejercicios de preparación escolar y en concreto de la etopeya a la teoría del arte de escribir cartas, véase A. J. Malherbe, «Ancient Epistolary Theorists», Ohio Journal of Religious Studies 5, 2, 1977, pp. 1314. Sobre la importancia del $\eta \theta 0 \varsigma$ en la preceptiva epistolográfica en general, véanse G. Reichel, Quaestiones Progymnasmaticae, Diss. Leipzig 1909, p. 87; y E. Suárez de la Torre, "Ars Epistolica. La preceptiva epistolográfica y sus relaciones con la retórica", en Estudios de Drama y Retórica en Grecia y Roma, Coord. G. Morocho Gayo, Univ. de León 1987, pp. 177-204.

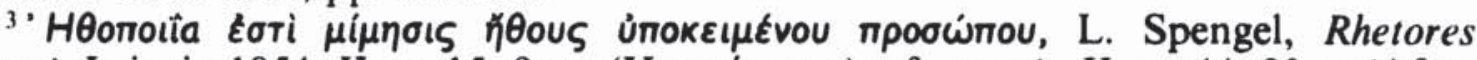
Graeci, Leipzig 1854, II, p. 15, 9 ss. (Hermógenes); cf. op. cit. II, p. 44, 20 ss (Aftonio) y op. cit., II, 115, 11 ss. (Teón); sobre la etopeya véase también op. cit., III, 488, 24 ss. (Nicolao). Sobre algunas coincidencias entre las definiciones de carta y etopeya, así como entre algunos rasgos de estilo de ambas, véase Apéndice I. Sobre la etopeya en general, véase Reichel, op. cit., pp. 75-88.

4 Cf. Spengel, op. cit., III, p. 491, 1 ss. (Nicolao).

s Ibidem.

6 Spengel, op. cit., II, p. 115, 20-22 (Teón).

7 Spengel, op. cit., III, p. 491,1 ss.

${ }^{8}$ Ejemplos de etopeya en forma de carta son AP IX 451-452. En ambos epigramas Filomela se dirige a su hermana Procne y le cuenta la violación que ha sufrido a manos de Tereo, esposo de ésta, quien además le ha cortado la lengua para que no pueda divulgarlo. Tanto el contenido del mito como determinadas fórmulas salutatorias confirman su naturaleza epistolar: según el mito, Procne bordó sus desgracias y de esa manera se las comunicó a su hermana; por otro lado, el inicio del epigrama 452 cuenta con una fórmula salutatoria propia de un texto epistolar: Xaĩ $\varepsilon$,

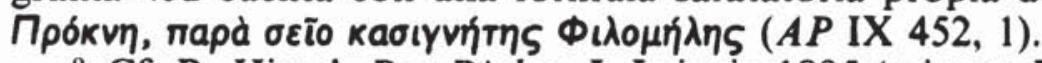

9 Cf. R. Hirzel, Der Dialog, I, Leipzig 1895 (reimpr. Hildesheim 1963), p. 330 ss. y 353 ss., y E. Suárez de la Torre, "La epistolografia griega», EC 83, 1979, p. 21 ss. y 37 ss. 
mensaje se halla en el cuerpo de las mismas. También en el cuerpo de carta encontramos marcas indicadoras de la existencia del emisor y receptor; a veces incluso los nombres de ambos. Pero no siempre sucede así y, en ocasiones, dichas marcas no existen o, si existen, contradicen la información ofrecida por el encabezamiento. Ello ocurre, por ejemplo, cuando el texto de una carta no parece estar dirigido a un "tú», sino que más bien se asemeja a un monólogo del "yo» protagonista que habla consigo mismo; o cuando el cuerpo de carta sugiere que el mensaje va dirigido a un grupo o a la divinidad, pero el encabezamiento presenta el nombre de un destinatario concreto e individualizado. Pues bien, estas y otras irregularidades nos hicieron sospechar de la naturaleza epistolar de alguna de las composiciones.

A nuestro juicio, los textos de Alcifrón, Eliano y Filóstrato ${ }^{10}$ son etopeyas en forma de carta; e incluso lo que en muchos casos se nos ha conservado como cartas ni siquiera lo son en sentido estricto. Efectivamente, son numerosas las cartas no dirigidas a nadie, sin destinatario. Parecen soliloquios de un determinado personaje, lo que en terminología retórica se llamaría una $\eta \theta 0 \pi o i t a ~ d \pi \lambda \tilde{\eta}^{\prime \prime}$, en la que el personaje habla consigo mismo. Tres ejemplos muy esclarecedores a este respecto son Alciphr. III 13, III 32, III 37. En todos ellos el interlocutor, un parásito, se queja a los dioses de su situación y lo hace de un modo direc-

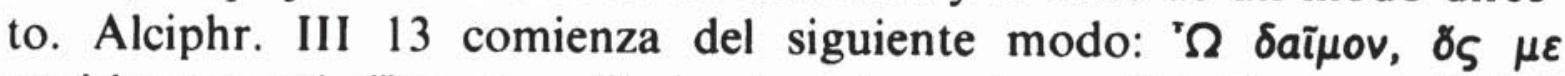

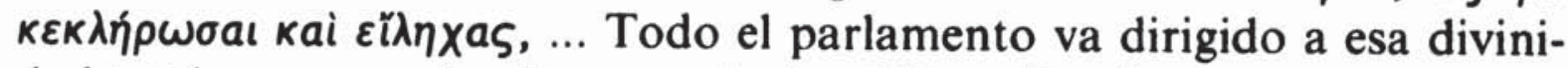
dad tutelar que, según el personaje, lo obliga, dice él, «a comer perifollo y ascidias o a recoger hierbas y llenar mi estómago bebiendo agua en la fuente Enneacruno" ${ }^{12}$ cuando no hay invitación. Por el contenido del cuerpo de la carta no parece que ésta vaya dirigida a otro parásito de nombre Aristómaco como indica el encabezamiento. En todo caso se trataría de una etopeya, que no carta, en la que un parásito se dirige a su divinidad tutelar en momentos harto dificiles para él. Lo mismo puede decirse de los otros dos ejemplos. Entre otras razones esto explicaría la falta de fórmulas salutatorias y de despedida en estas y otras muchas

${ }^{10} \mathrm{El}$ corpus de referencia serán las epístolas ficticias de personajes ficticios atribuidas a Alcifrón, aunque también haremos alusión a los nombres encontrados en las de Eliano y Filóstrato. La edición seguida es la de A. R. Benner y F. H. Fobes, The Letters of Alciphron, Aelian and Philostratos, Londres 1949. No incluimos nombres de personajes como Hiperides, Frine, Demetrio, Lamia, Menandro y Glicera, Praxiteles, etc., es decir, nombres de personajes no ficticios; en cambio sí serán incluidos otros que hacen referencia a personajes-tipo de comedia.

"Cf. Spengel, op. cit., II, p. 15, 22 ss. (Hermógenes).

12 E. Ruiz García, Teofrasto. Caracteres. Alcifrón. Cartas de pescadores, campesinos, parásitos y cortesanas, Madrid 1988, p. 246. 
cartas. Por lo mismo, la ausencia de rasgos en los protagonistas no ha de resultarnos extraña si pensamos en un tipo de etopeya como la de

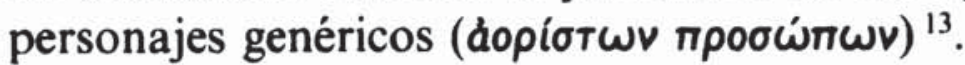

4. En el análisis y clasificación de las composiciones nos hemos ceñido, pues, a la información que proporcionan los textos al margen de los encabezamientos. Hemos analizado la forma y el contenido, buscado marcas y expresiones propias de la comunicación epistolar; $y$, aun reconociendo que muchas veces la clasificación es discutible, podernos hablar de: 1) composiciones en las que no encontramos datos en el texto que demuestren que están dirigidas a nadie en concreto y cuando los textos, como en los ejemplos anteriormente citados, parecen más bien soliloquios o monólogos de los protagonistas; 2) composiciones dirigidas a alguien más o menos definido; 3 ) probable carta, si el contenido del texto sugiere que estamos ante una carta, como cuando existe distancia entre los interlocutores; 4) carta segura, cuando el contenido y la forma confirman que se trata de una carta, generalmente porque se hace mención expresa de la carta o porque el texto cuenta con fórmulas de saludo o despedida que revelan su naturaleza epistolar. Muchas veces esa naturaleza epistolar viene aclarada por el envío de a!gún objeto que acompaña la carta. A los dos primeros tipos nos referiremos, haciendo uso de la terminología retórica, como «etopeyas simples» ( $(n \lambda \lambda a \tilde{)})$

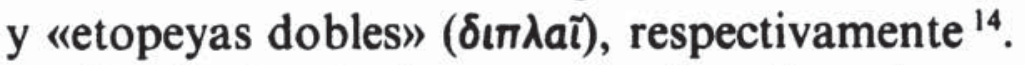

Por lo demás, la ausencia de referencias a un interlocutor definido en el cuerpo de texto o la falta de indicadores de la naturaleza epistolar dentro del mismo no presuponen necesariamente que nos encontremos ante algo distinto a una carta. Sin embargo, ello, unido a otros datos, parece sugerir en algún caso una naturaleza distinta a la epistolar, al menos por lo que se deduce del cuerpo de carta.

\section{Alcifrón, Eliano y Filóstrato}

5.1. Alcifrón, Eliano y Filóstrato compusieron durante los siglos II y ill d.C. tres conjuntos de cartas. Filóstrato es autor de una colección de cartas de amor; de Eliano se nos conserva una veintena de cartas de campesinos; y Alcifrón presenta el conjunto más variado, compuesto por cartas de marineros, campesinos, parásitos y heteras. El análisis de

${ }^{13}$ Spengel, op. cit., II, p. 15, 18 (Hermógenes); cf. II, p. 115 (Teón) y III, p. 489 (Nicolao). En Libanio encontramos algunos ejemplos, cf. R. Foerster, ed., Libanii Opera, vol. III, Leipzig 1915, pp. 414-421.

${ }^{14}$ Cf. Spengel, op. cit., II, p. 15 (Hermógenes). 
las cartas de estos tres autores, de acuerdo con los criterios previamente establecidos, ha dado como resultado la siguiente clasificación:

5.1.1. En Alcifrón encontramos las siguientes «etopeyas simples»: I 13, I $15^{15}$, II 1 , II 4 , II 10 , II 19 , II 21 , II 23 , II 33 , II 34 , II 38 , III 2 , III 4, III 8 , III 13, III 16, III 17, III 21, III 25, III 29, III 31 , III 32 , III 33, III 34, III 36, III 37, III 38, III 40, III 42; «etopeyas dobles» (varias entre personas próximas de una familia) ${ }^{16}$ : I 3, I 6, I 8 , I 11-I $12^{17}$, II 8, II 11, II 22, II 31; otras: I 1, I 9, I 10, II 2, II 3, II 5, II 6-II 7, II 9 , II 12 , II 15 , II 17 , II 18 , II 24-II 25 , II 26 , II 30 , II 32 , II 35 , III 1 , III 3, III 5, III 6, III 7, III 10, III 11 , III 12 , III $18^{18}$, III 19 , III 20 , III 22 , III 23 , III 26 , III 27 , III 28 , III 30 , IV 3 , IV 4 , IV 5 , IV fr. 5 .; probables cartas: I 2, I 4, I 5, I 21-I 22, II 16, II 28, II 29, III 9, III 15, III 24, III 35, IV 6, IV 9, IV 10, IV 12; cartas seguras: I 7 (envio), I 17-I 18-I 19, II 20 (envío), II 27 (envío), III 39, IV 1, IV 2, IV 7, IV 8, IV 11, IV 13, IV 14, IV 15, IV 16, IV 17, IV 18, IV 19, y tal vez II 37 y II 39 (envío).

5.1.2. En Eliano, «etopeyas simples»: 1, 5 y 19; «etopeyas dobles»: $3,4,10,17,18$; cartas probables: 6,9 ; cartas seguras: $2,7-8$ (envio), 11 12, 13-14-15-16, 20.

5.1.3. En Filóstrato, «etopeyas simples» o más bien apotegmas (äпофөє́үната): 43, 52 y tal vez 65; «etopeyas dobles»: 3, 5, 6, 7, 10, 11 , $12,13,15,17,19,20,22,23,24,25,26,27,28,29,30-31,32,33,34$, $35,36,37,38,40,41,42,44,47,48,50,52,53,55,56,57,58,60,61$, $64,65,66,67,68,69,71,72$; cartas probables: $9,16,21,59,73$; cartas seguras: 1 (envío), 2 (envío), 4, 8, 14, 39, 45 (envío), 46 (envío), 49 (envío), 54 (envío), 63, 70.

5.2. Por lo que se desprende del análisis, es posible que las colecciones de textos de Alcifrón, Eliano y Filóstrato estén compuestas por ejercicios etopéyicos, muchos de los cuales, aunque no todos, se presentan en forma de carta. La naturaleza escolar de todos ellos justifica la utilización del epíteto $\rho \dot{\eta} \tau \omega_{p}$ referido a Alcifrón por parte de Tzetzes ${ }^{19}$

15 Sobre el posible empleo en cartas del plural "nosotros" en sentido genérico (nosotros los pescadores, campesinos, parásitos o heteras), cf. Alciphr. I 15, II 32, III 2, III 8, IV 3, IV Fr. 5, cf. I 4 y Ael. 20.

${ }^{16}$ No existe indicación de que estén separadas como ocurre en Alciphr. I 4, II 37 $y$ tal vez II 13.

17 No creemos que la existencia de una respuesta obligue a pensar en una carta. Una etopeya de respuesta supondría un esfuerzo mayor, pues habría que tener en cuenta lo dicho por otro personaje.

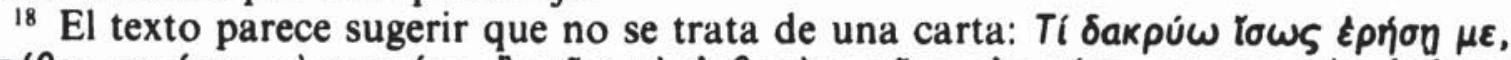

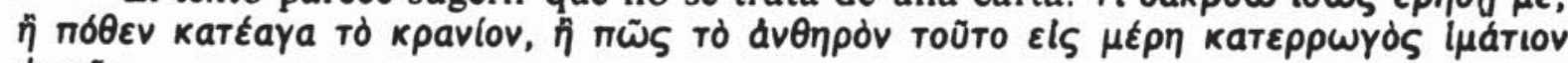

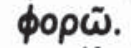

${ }_{19}$ Scholia ad Chiliades VIII 8895. 
y ya presente en los títulos de los manuscritos más antiguos de Alcifrón ${ }^{20}$, así como el epíteto "sofista" que acompaña a los nombres de los autores de cartas como Filóstrato ( $s$. $u$. en la Suda) y Eliano (Philostr. $V S$ 624) ${ }^{21}$. También otros autores de epístolas son denominados por el correspondiente autor de la Suda con tales apelativos: de Teofilacto, al igual que de Melesermo, dice que era ooфiorís; de Zoneo dice Constantino Paleócapa, modificando el texto de la Suda, que se le atribuyen...

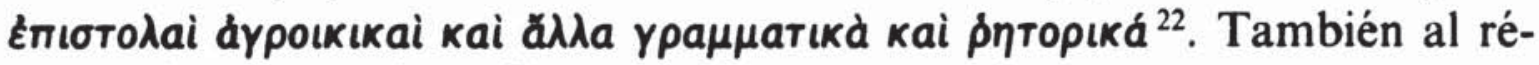

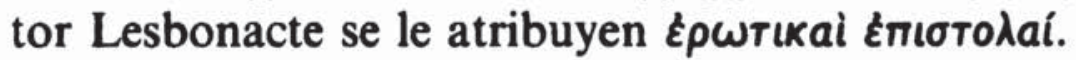

5.3. Hay otras razones que nos hacen sospechar de los nombres utilizados en los encabezamientos de Alcifrón, Eliano y Filóstrato, pero especialmente del primero. En efecto, los nombres han sido añadidos con anterioridad a la clasificación de las cartas en grupos ${ }^{23}$ tal y como la conocemos hoy (de pescadores, campesinos, parásitos y heteras), clasificación que fue llevada a cabo por Shepers en su edición de 1901. No hay que descartar otras clasificaciones anteriores ajenas al propio autor y de acuerdo con las cuales se habrían aplicado los nombres, aunque con ello no pretendemos descartar la posibilidad - prácticamente segura y en gran medida confirmada por la tradición manuscrita - de que el propio Alcifrón escribiera cartas o etopeyas agrupadas temáticamente ${ }^{24}$. Ya la adscripción de una carta a uno $u$ otro grupo, tal y como se nos presentan en nuestras ediciones, es discutible: así II 32 estaría mejor ubicada en el grupo de cartas de parásitos, como por otra parte confir-

${ }^{20}$ Cf. J. R. Vieillefond, "L'invention chez Alciphron», REG 92, 1979, p. 123, n. 5.

${ }^{21}$ Cf. T. C. Burgess, «Epideictic Literature», Studies in Classical Philology 3, 1902, p. 186.

${ }^{22} \mathrm{H}$. Gärtner, "Zonaios», RE XA, col. 718.

${ }^{23}$ Ello por no citar la inadecuación de títulos como los de Alciphr. III 1 y III 2; cf. M. A. Shepers, Alciphron. Epistulae, Leipzig 1905 (reimpr. Stuttgart 1969), pp. 57-58.

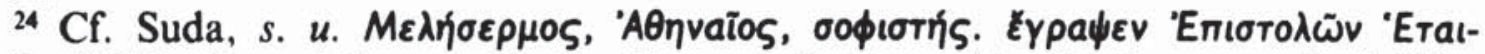

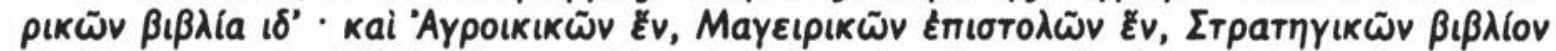

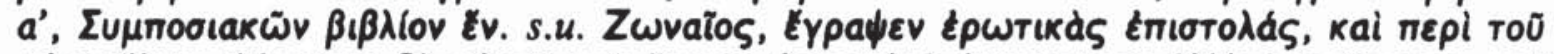

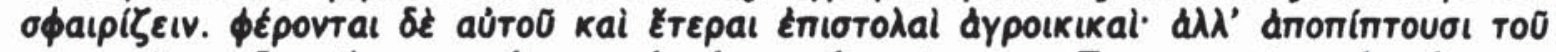
характі́роs. Los tipos son los empleados en las etopeyas. En concreto, sobre los generales del ejército, véase Spengel, op. cit., II, p. 116, 10-16 (Hermógenes) y II, 15 , 25-28 (Teón); y C. Halm, Rhetores Latini Minores, Leipzig 1863, p. 515, 3-4 (Isidoro); sobre el $\eta \theta 0 \varsigma$ de general hace referencia Hermógenes [Spengel, op. cit., II, p. 350, 17 (Hermog. Id. 304)]. En cuanto a las cartas de heteras pueden ofrecerse como paralelo Los diálogos de heteras de Luciano o una etopeya de Libanio titulada

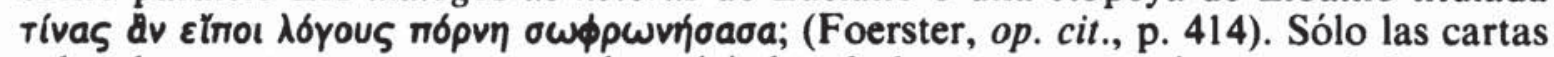
sobre banquetes parecen estar algo alejadas de la etopeya y más cerca de la narración (cf. Sykutris, art. cit., col. 216), aunque igualmente el término podría abarcar composiciones como Alciphr. II 30 y II 34. 
ma la tradición manuscrita; III 6 , al igual que III 18 , no son necesariamente de parásitos sino de jugadores con poca fortuna; III 16 más parece de esclavos que de parásitos ${ }^{25}$, aunque los nombres de sus protagonistas transmitidos por los encabezamientos corresponden indiscuti-

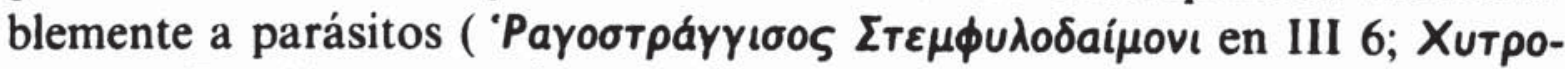

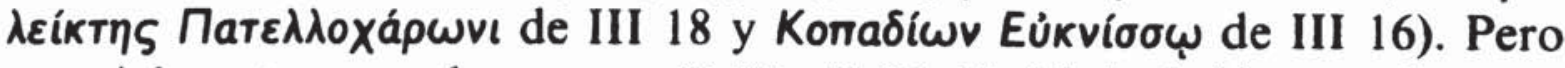
especialmente sospechosas son II 30 , II 34 , II 35 , incluidas en el grupo de cartas de campesinos, por cuanto que ninguno de los tipos que da título a cada uno de los libros parece acomodarse por completo al contenido de las mismas. Las dos primeras tratan sobre las consecuencias de una borrachera y la molesta presencia de un fanfarrón en un banquete, y ambas son mejor ubicadas por la tradición manuscrita entre las de parásitos; la tercera es el relato de una violación de las que tantos ejemplos nos ofrece la Comedia Nueva, como confirma también la presencia del nombre Mosquión; esta carta no cabe en ninguna de estas clasificaciones. Incluso nos atreveríamos a dudar que II 7 sea una respuesta a II 6 como sugieren los encabezamientos. En II 6 alguien echa en cara a una joven que a pesar de haber recibido muchos obsequios suyos no le preste atención; en II 7 una joven amenaza a un viejo verde que intentó asaltarla. Con todo, pudiera suceder que los títulos fuesen los únicos criterios fiables para su clasificación, pero únicamente en el caso de que hubieran salido de la mano de Alcifrón. Por otra parte, y aunque no es posible saber qué estaba pensando el autor cuando daba nombre a sus personajes, algunos de ellos parecen no haber sido muy bien aplicados. Así ocurre con nombres de agricultores que corresponderían mejor a pastores ${ }^{26}$, aunque la distinción entre tales figuras no es demasiado clara en algunos textos, ni tampoco en el propio ámbito del campo griego, donde algunos propietarios de terrenos mantenían al tiempo rebaños.

5.4. La presentación de los encabezamientos de carta es variada. En la transmisión de los textos de Alcifrón, si bien las cartas II 1 y IV

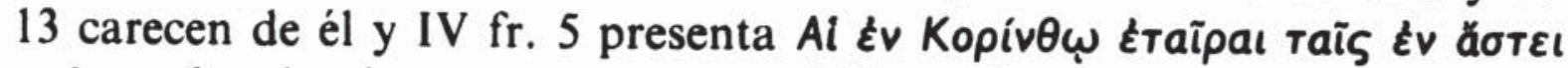
xaipeıv, las demás, como ocurre también en las cartas de Eliano, Aris-

${ }^{25}$ Cf. también Alciphr. III 22; sin embargo un tema parecido en III 26 aparece referido a un parásito.

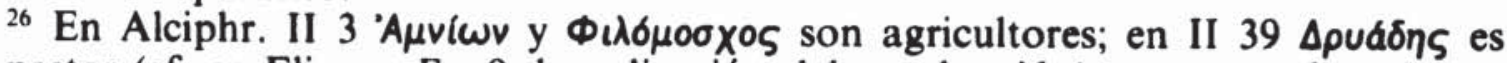

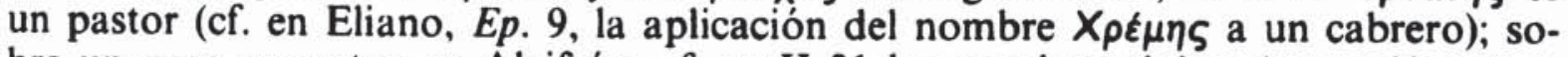

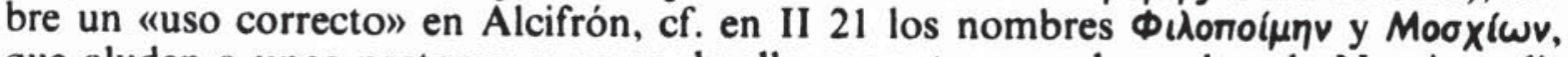
que aluden a unos pastores; a pesar de ello encontramos el nombre de Nomio aplicado a un campesino en el cuerpo de carta en II 22. De todos modos en Alcifrón ninguno de los personajes que podemos calificar de pastores es presentado en el cuerpo de carta. 
téneto y Teofilacto, cuentan con el nombre del remitente en nominativo

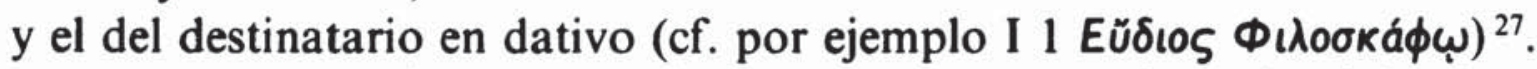
Por contra, en Filóstrato lo más frecuente es una referencia al destina-

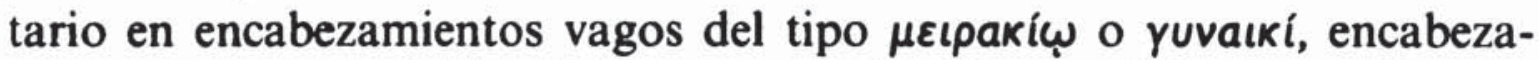
mientos que, en opinión de Benner y Fobes ${ }^{28}$, son adiciones tardías. En ocasiones también hallamos nombres de destinatarios ${ }^{29}$. Estas diferencias en la presentación de las cartas de los distintos autores quizá sólo tengan que ver con ellos de modo indirecto. En efecto, lo que han hecho quienes han añadido los encabezamientos es servirse de los datos y los nombres tal y como los encontraban en los distintos epistológrafos. Alcifrón incluye en numerosas ocasiones el nombre del interlocutor en el cuerpo de carta. Además, puesto que existen algunas cartas de respuesta, es posible identificar los nombres tanto del remitente como del destinatario. Si a ello añadimos el hecho de que pueden observarse criterios de creación y recreación por parte de Alcifrón en los nombres encontrados en el cuerpo del texto, y no falta algún catálogo de nombres en éste del que poder hacer uso para tales menesteres, tenemos todos los ingredientes para que los «tituladores» intentaran completar algo que muy posiblemente no existió, encabezamientos de carta. En el caso de Eliano ${ }^{30}$ tales criterios son menos claros y tampoco se encuentran

27 Los ejercicios etopéyicos aportados por los rétores en sus manuales presentan

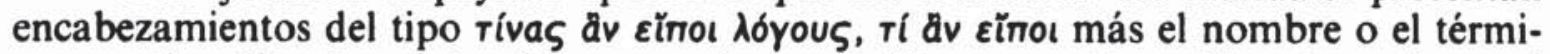
no que describe el carácter del personaje que habla y a continuación el nombre o el término que describe el carácter del personaje al que van dirigidas las palabras o la situación en que dicha intervención tiene lugar. Algunos ejemplos de encabezamiento de etopeya de personajes genéricos serían: «iqué diría a los suyos alguien antes de partir lejos del país?» [Spengel, op. cit., II, p. 15, 19-20 (Hermógenes)]; "iqué palabras diría un general a su ejército después de la victoria?» [Spengel, op. cit., II, p. 15, 26-28 (Hermógenes)]. Lo mismo cabe decir para etopeyas de personajes definidos. Ese es el tipo de encabezamiento que hallamos también en Libanio. Por contra, los ejercicios de alumnos encontrados en el P. Heidelberg 1271 (verso) muestran la elipsis de la parte "qué palabras diría". Tal vez ello se deba a la concisión propia de los apuntes de alumnos. En la Antología Palatina encontramos un grupo de etopeyas (IX 451 ss., 457 ss., 460 ss.), encabezadas asimismo por el epígrafe rívas dv عinoı $\lambda \delta-$ yous, Ti dv cinoı. Sin embargo, dichos lemmata no siempre son fiables (cf. por ejemplo $A P$ IX 463, que, según el lemma, está puesto en boca de Héctor, pero en una nota al verso 3 Waltz, el editor, muestra su asombro ante tal asignación a la vista de la alusión al propio Héctor en dicho verso).

${ }^{28}$ Benner y Fobes, op. cit., p. 414-415 n. 2. Frecuentemente las distintas lecturas de los manuscritos, especialmente los cambios de sexo, se deben a la ausencia de indicaciones en el cuerpo de texto sobre los mismos, unido todo ello a los prejuicios de los encargados de la transmisión manuscrita respecto a la homosexualidad.

${ }^{29}$ Cf. infra Apéndice II) 3 B).

30 Sobre los nombres empleados por Luciano, y que también se encuentran en Alcifrón, véase P. M. L. Leone, "Sulle epistole rustiche di C. Eliano», AFLM 8, 1975, pp. 47-50. 
pasajes significativos a este respecto. Como veremos, los autores de encabezamientos se limitarán a repetir nombres encontrados en el cuerpo del texto. En Filóstrato prácticamente no existen en el cuerpo de carta nombres de personajes ficticios con los que poder confeccionar los encabezamientos $^{31}$, lo que explica la vaguedad a la que Benner y Fobes hacían referencia.

5.5.1. Partimos de la premisa de que los nombres incorporados en el texto de la carta sí corresponden a los autores. Pues bien, en tales nombres, porcentualmente hablando, no se observa una inclinación tan exagerada a la creación en el caso de Alcifrón ${ }^{32}$. Es más, el estudio por grupos muestra un uso muy semejante al de Luciano. Lo mismo puede decirse de los transmitidos para Eliano ${ }^{33}$.

5.5.2. Por lo que respecta a Alcifrón, determinados nombres de cuerpo de carta encontrados en los distintos grupos parecen haber guiado la confección de otros. Así ocurre en el grupo de pescadores con

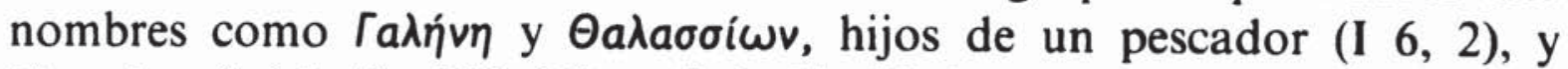

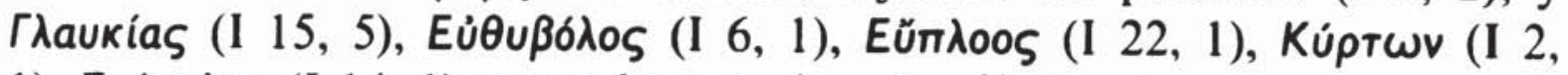

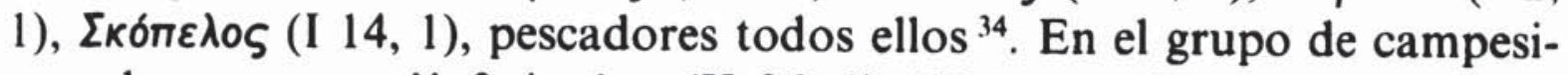

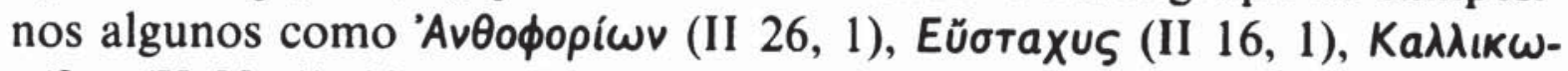

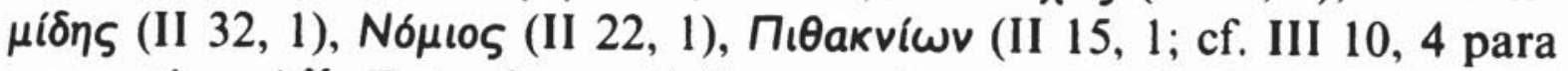

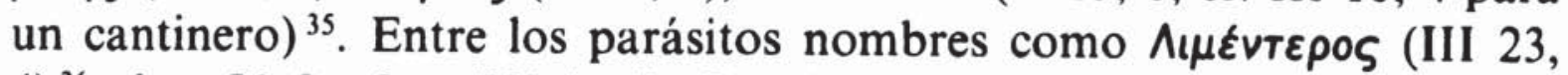

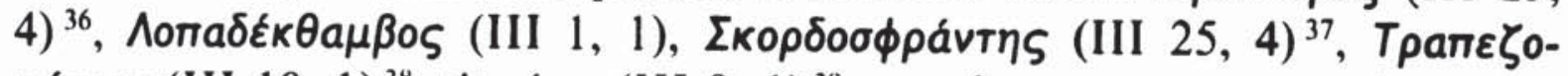
xápwv (III 10,1) ${ }^{38}, \boldsymbol{\psi}$ ‘xíwv (III 9,1$)^{39}$, nombres que en general son ex-

${ }^{31}$ Cf. infra Apéndice II) 3 A).

${ }^{32} \mathrm{Cf}$. infra Apéndice II) 1 A).

${ }^{33} \mathrm{Cf}$. infra Apéndice II) $2 \mathrm{~A}$ ).

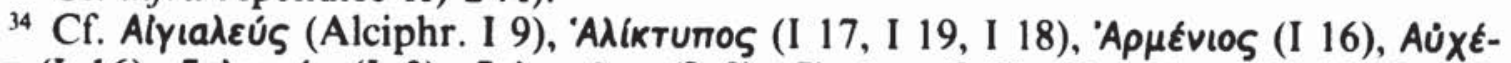

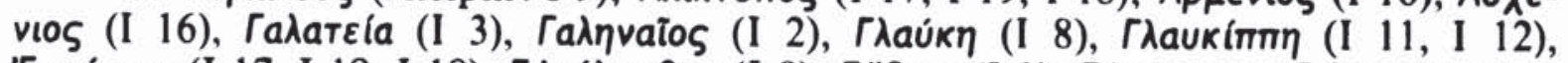

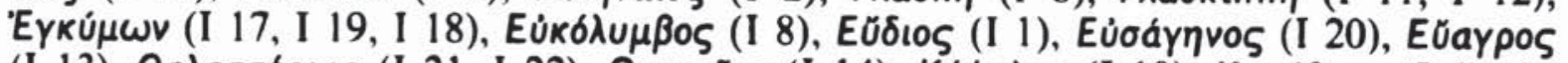

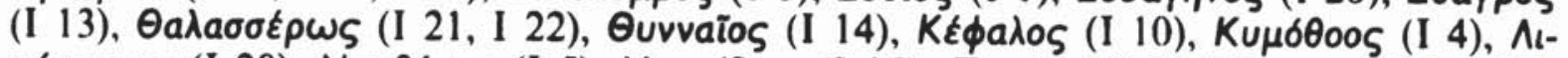

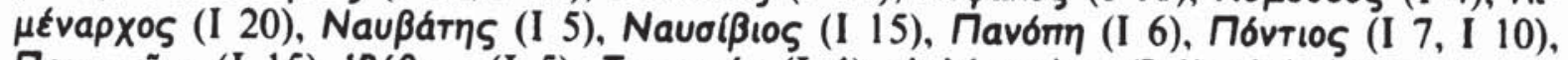

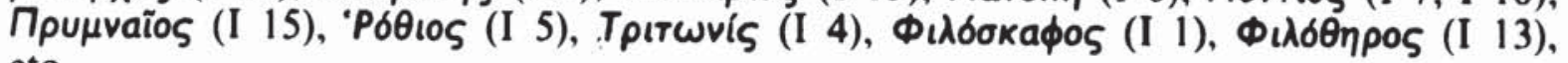
etc.

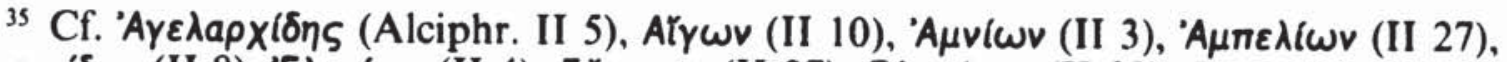

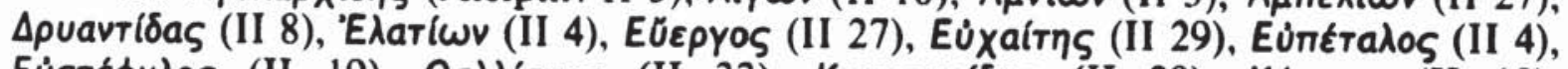

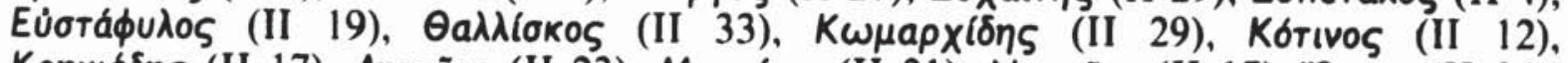
Kpquidóns (II 17), Anvaĩos (II 23), Mooxiwv (II 21), Nanaĩos (II 17), "Oplos (II 26),

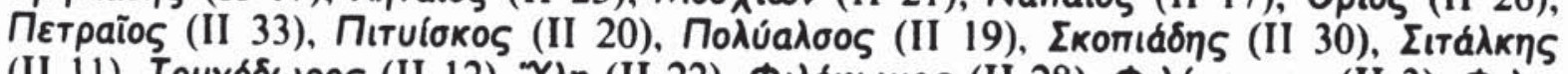

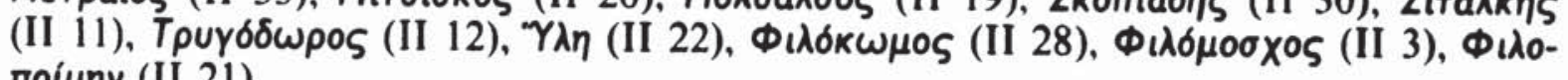
поí $\mu \eta v$ (II 21).

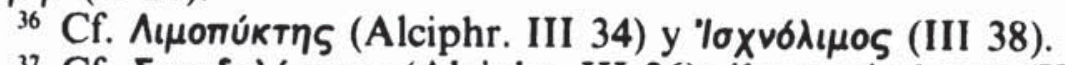

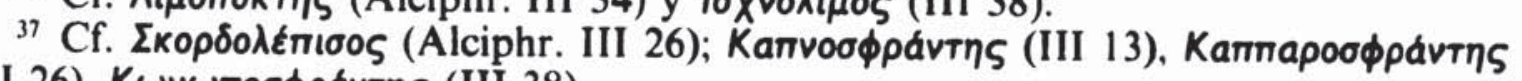

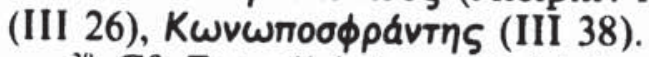

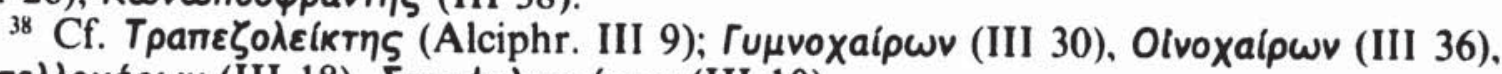

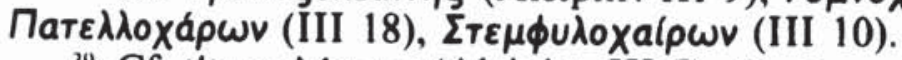

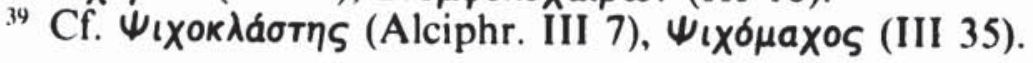


plicados por el propio autor. Obsérvese, por ejemplo, el juego de palabras entre Polibio («rico en recursos») y Escordosfrantes («hueleajos») en III 25,4 , nombres de un personaje antes y después de convertirse en parásito. En el grupo de heteras los nombres presentados en el cuerpo de carta ${ }^{40}$ han servido para rellenar lagunas en los encabezamientos ${ }^{41}$. El pasaje IV 14, 2 parece haber of recido a los autores de encabezamientos nombres para los mismos ${ }^{42}$. Un nombre como el de Nikimm (IV 10), ha debido de ser favorecido por otros como Eú ̧ínm (IV 6, 1 y IV

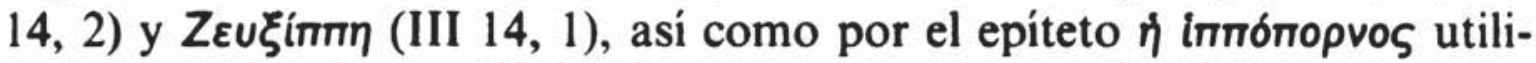
zado para Zeuxipe en III 14, 1 y para Partenion en II 31, 2.

5.6. En cuanto a la temática y tipologia, hemos de decir que Alcifrón y Eliano, como luego hará Aristéneto, se nutren de la Comedia Nueva. Muchos de los temas, el ambiente y los tipos proceden de Menandro ${ }^{43}$. Pero ello no tiene nada de extraño si recordamos las palabras del rétor Teón cuando al hablar de la nueva educación y de sus mode-

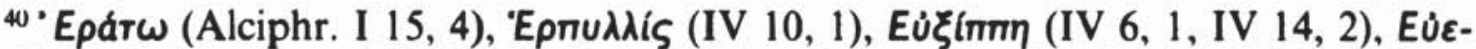

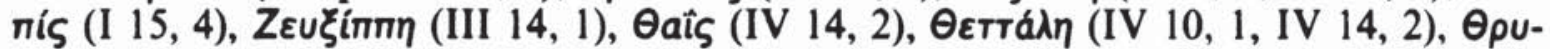

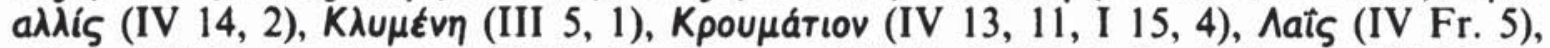

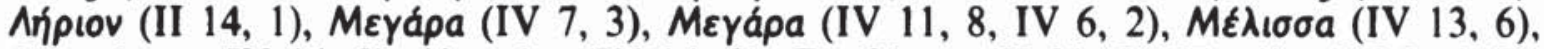

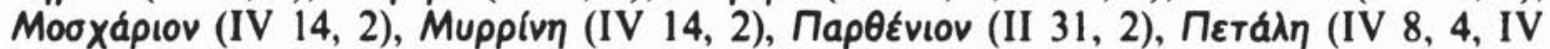

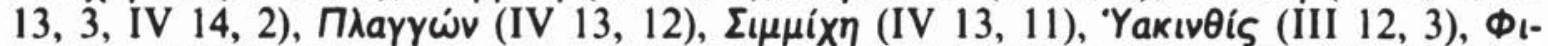

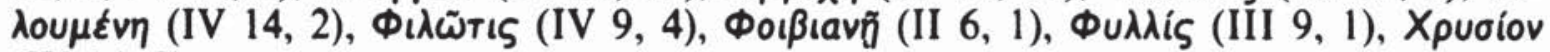
(IV 14, 2).

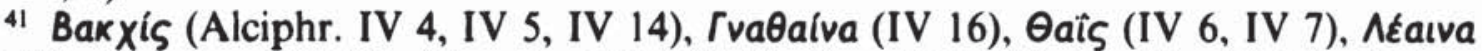

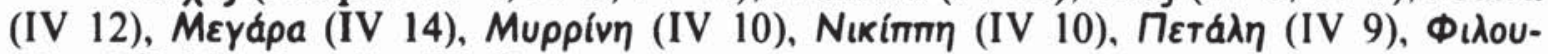

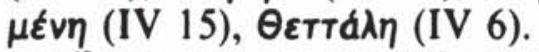

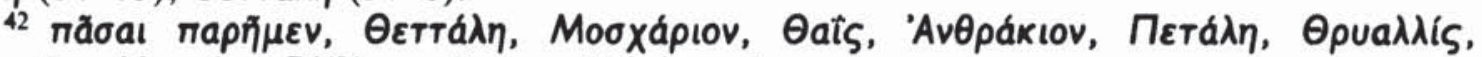

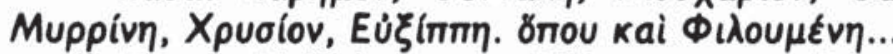

${ }^{43}$ Tanto Alcifrón como Filóstrato mencionan el nombre de Menandro. El primero hace de él autor de algunas de sus cartas y destinatario de una (Philostr. 16, 38, 47; Alciphr. IV 2, IV 3, IV 18, IV 19). Sobre el uso por parte de epistológrafos y rétores de Menandro, véase A. A. Day, The Origins of Latin Love-Elegy, Oxford 1938 (reimpr. Hildesheim 1984), pp. 37, 44, y especialmente 62 ss. Sobre la temática y fraseologia menandrea en Eliano y Aristéneto, véase W. G. Arnott, «Pastiche, pleasantry, prudish eroticism: the letters of Aristaenetus'", YCIS 27, 1982, p. 301 ss. y p. 306 ss. Véanse también W. G. Arnott, "Aristaenetus und Menander's Dyskolos», Hermes 96, 1968, 384 y O. Mazal, «Aristainetos und Menander 'Dyskolos'», en Studi Classici in honore di Q. Cataudella, II, Catania 1972, pp. 261-264. Sobre la temática de las cartas de Alcifrón y sus fuentes, véase el completísimo estudio de L. Previale, "L'epistolario di Alcifrone", Il Mondo Class. 2, 1932, pp. 38-72 y G. Carugno, "Intrighi familiari, inesperienza ed ignoranza dei contadini nelle Epistole rustiche' di Alcifrone», GIF 13, 1960, pp. 135-145 y "Reflessi comici in alcuni tipi di servi nelle epistole rustiche di Alcifrone», GIF 16, 1963, pp. 350-351. Sobre el uso en general de la comedia, véase la bibliografia ofrecida por A. S. Gratwick, "Sundials, parasites, and girls from Boeotia», $C Q 29,1979$, p. 309 n.3. Posteriormente puede verse $P$. Magrini, «Lessico platonico e motivi comici nelle 'Lettere erotiche' di Aristeneto", Prometheus 7, 1981, pp. 146-158, y G. Zanetto, "Un epistolografo al lavoro: Le Lettere di Aristeneto", SIFC 5, 1987, 193-211. 


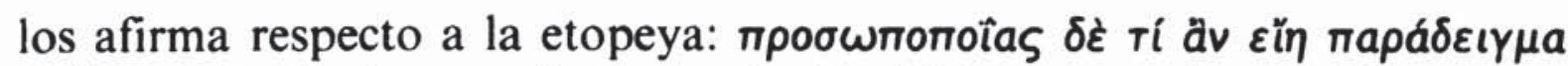

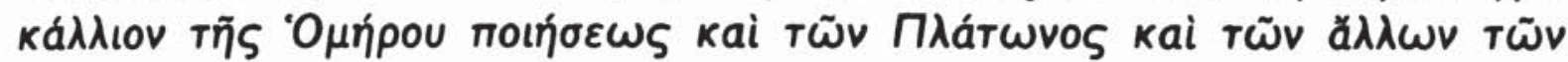

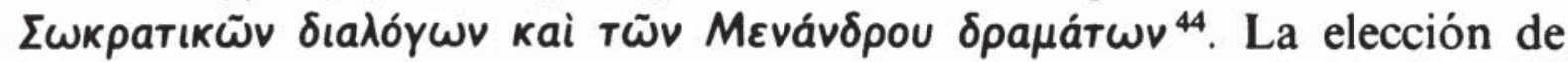
campesinos y marineros por parte de Alcifrón queda justificada por boca de Hermógenes cuando al referirse a la $a \phi \varepsilon \lambda \varepsilon i ̃ a$ "simplicidad» en su Sobre formas de estilo habla de dos tipos distintos. El primero - que es el que ahora nos interesa - es una forma de simplicidad apropiada para la caracterización de seres sencillos y sin maldad, pero poco útil para el discurso político. Los pensamientos expuestos son propiamente simples y puros como los que proceden de los niños, de hombres y mujeres infantiles, inocentes, de campesinos rústicos, de pastores, etc. ${ }^{45}$ Pues bien, muchos ejemplos de caracteres como éstos pueden hallarse, según Hermógenes ${ }^{46}$, en Anacreonte y Menandro. En las obras de estos autores, dice, es posible encontrar mujeres y jóvenes enamorados que expresan sus sentimientos, cocineros, doncellas desdeñosas, campesinos glotones y similares. También los textos de los rétores latinos Isidoro y Emporio confirman dicha temática para la etopeya ${ }^{47}$.

5.7. Según nuestra hipótesis, el rétor Alcifrón compuso una serie de etopeyas, la mayoría, aunque no todas, en forma de carta. Lo mismo puede decirse a este respecto de Eliano y Filóstrato. La temática es relativamente variada y los tipos responden a las figuras simples más recomendadas por los autores de los manuales de retórica. Posteriormente, y de acuerdo con la tradición manuscrita, la obra ha sido dividida en libros en los que se incluian las composiciones que tratan de un determinado tipo. Con todo no son pocas las que resulta difícil incluir en cualquiera de ellos. En general, ya lo hemos dicho, tratan de reflejar tipos y situaciones, y los personajes son genéricos (por ejemplo, el parási-

${ }^{44}$ Spengel, op. cit., II, p. 68, 22 (Teón).

45 Sobre este aspecto véase Burgess, art. cit., p. 188, donde recuerda un ejemplo

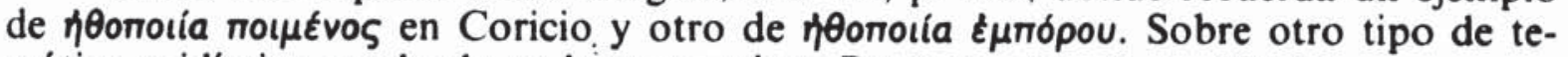
mática epidíctica empleada en la carta, véase Burgess, art. cit., p. 186 ss.

${ }^{46}$ Spengel, op. cit., II, p. 351, 7 - 352, 28 (Hermog. Id. 305-307).

47 Isidoro: Nam cum piratae persona suscipitur, audax, abrupta, temeraria erit oratio: cum feminae simulatur, sexui conuenire debet oratio: iam uero adulescentis et senis et militis et imperatoris et parasiti et rustici et philosophi diuersa oratio dicenda est (Halm, op. cit., p. 515, 1 ss.); Emporio: Aliter enim orationem uel incipit uel exequitur iratus, aliter timens, aliter gaudens, aliter tristis, aliter senex, aliter iuuenis, aliter uir, aliter femina. Refert in dicendo, deus an homo sit, lasciuus an tetricus, ignauus an fortis, doctus an rusticus. Sit igitur alacris lactantis oratio, tumens uani, breuis et concisa properantis, meretriculae mollis et blanda, matronae seria, senum grauis, temeraria pueri, misera humilis, longa et multa ambiens confitentis, parasiti faceta, matris anxia, incondita rustici, oratoris ornata (Halm, op. cit., p. 562, 1 ss.). Aunque ya desde Aristóteles y Quintiliano poseemos tal información (véase Reichel, op. cit. p. 85 ss.). 
to que no tiene banquete al que acudir). La temática procede principalmente de la comedia de Menandro. No faltan tampoco los nombres. El cuerpo de carta aporta una lista con nombres creados en la misma línea que Luciano. Cuando tienen lugar invenciones como las de Escordosfrantes, Liméntero, Lopadectambo, Siquión o Trapezocaronte, son explicadas y funcionan más como epítetos que como nombres de esos tipos genéricos. Alcifrón muy probablemente nunca escribió encabezamientos, pero la presencia de estos y otros nombres ha hecho que se compusieran algunos verosímiles (como ocurre cuando existe una carta de respuesta y en ambas los nombres de los interlocutores han sido presentados), otros conformados con nombres tomados del corpus que el texto de las cartas ofrecía o creados según los criterios que parecían desprenderse de los encontrados en los textos de las cartas. Incluso a las "etopeyas simples", que no iban dirigidas a nadie, se les ha puesto encabezamiento con dos nombres. Otra forma muy utilizada por estos «tituladores» es la de añadir encabezamientos con dos nombres emparejados por sus significados ${ }^{48}$. Se observa igualmente la tendencia a crear nombres compuestos con sufijo $-\pi \eta S^{49}$, mientras que nombres de este tipo son muy poco frecuentes en el cuerpo del texto (apenas uno o dos) ${ }^{50}$. A diferencia de Alcifrón y Eliano, en Filóstrato la ausencia de tales nombres en el cuerpo de carta ha dado lugar a encabezamientos más vagos.

\section{Aristéneto}

6.1. También en Aristéneto ${ }^{51}$ se confirman las conclusiones a que hemos llegado respecto a Alcifrón, Eliano y Filóstrato ${ }^{52}$. Aristéneto es un epistológrafo del siglo $v$ d.C. sobre cuya identidad planea la sombra de la duda, pues algunos investigadores sostienen - creemos que tal vez

${ }^{48}$ Ct. Alciphr. I 3. I 7, I 13, I 16, I 17-I 18-I 19, II 3, II 4, II 17, II 21, II 28 , III 3, III 4, III 5, III 6, III 10, III 21.

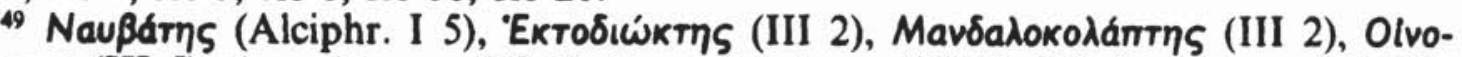

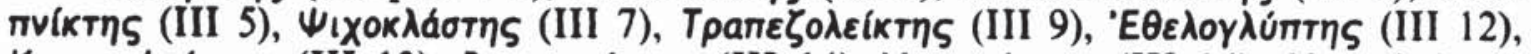

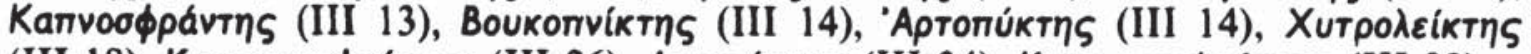

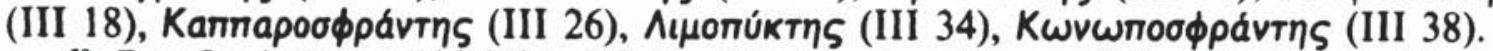

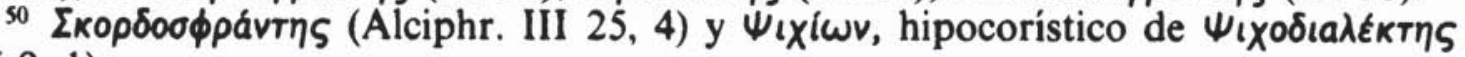
(III 9, 1). 1971.

51 Para este autor hemos seguido la edición de O. Mazal, Aristaenetus, Stuttgart

52 Cf. A. Lesky, Aristainetos: Erotische Briefe, Zurich 1951, p. 44 ss., donde trata sobre la importancia de los ejercicios de preparación ( $\mathrm{y}$ en concreto las etopeyas) en la formación de los rétores. 
con acierto - que Aristéneto es el nombre del remitente, del interlocutor de la carta I 1, y no el del autor o coleccionista de las cartas ${ }^{53}$.

6.2. Pues bien, cinco de las cartas de Aristéneto (I 14, II 8, II 10, II 11, II 12), por citar los ejemplos más claros, se corresponden, por su estructura y contenido, mejor con etopeyas que con cartas: en I 14 una hetera se dirige a un grupo de jóvenes, y no a uno solo como sugiere el título ${ }^{54}$, para recomendarles que lleven dinero y dejen de querer ganarse a las heteras tocando flautas, cítaras, etc.; en II 8 un esposo enamorado de su suegra cuenta su situación y pide a los dioses que lo aparten de la impiedad; en II 10 un pintor enamorado del retrato de una joven se lamenta y pide a los amorcillos que le den vida a la imagen ${ }^{55}$; en II 11 un joven que ama al tiempo a su esposa y a una hetera pide a los amorcillos poder vivir con ambas sin que los celos surjan entre ellas; en II 12 un hombre rico casa con una chica pobre por compasión y posteriormente se lamenta de la soberbia y arrogancia de la nueva rica.

6.3. Además, y, como recuerda Schmid al referirse en concreto a los relatos de tema novelístico en los que se cuentan las aventuras de una persona distinta a la que habla, «... die Einkleidung novellistischer Gegenstände in Briefform ganz äusserlich ist» ${ }^{56}$. Nosotros diriamos que también aquellas composiciones en las que se narran las propias aventuras $^{57} \mathrm{e}$ incluso las que incluyen descripciones resultan sospechosas, excepción hecha, claro está, de las que cuentan con alguna fórmula o

${ }^{53}$ Véase W. G. Arnott en su reseña a la edición de O. Mazal, Gnomon 46, 1974, p. 353 s., y art. cit., donde además refiere la bibliografia anterior en torno a esta cuestión. Para Zanetto, Aristéneto es el nombre del autor de la colección y del remitente "ficticio" de la carta (art. cit., p. 200).

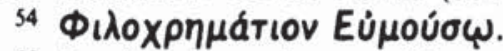

${ }^{55}$ Lesky, op. cit., p. 46, se refiere a esta composición llamándola «Monólogo del pintor». Sobre el mismo tema y con parecido tratamiento hallamos en Libanio una

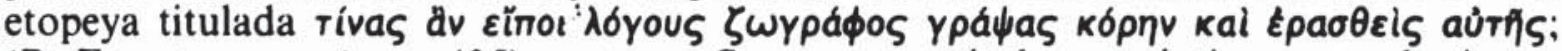
(R. Foerster, op. cit., p. 435) y otra en Severo cuyo título es prácticamente el mismo:

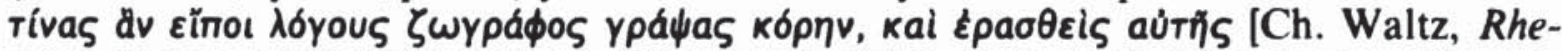
tores Graeci, 1832-1836 (reimpr. Osnabrück 1968), I, p. 546]. El tema ha sido rastreado por Day (op. cit., pp. 72-73). Un texto realmente interesante a este respecto es la declamación del sofista Enomarco sobre un hombre que se enamoró de una estatua, declamación que recoge Filóstrato en VS 598-599.

${ }^{56}$ W. Schmid, "A ristainetos", $R E$ II, 1965, col. 851. No estamos, sin embargo, de acuerdo con el autor cuando incluye en el grupo de cartas que relatan historias de amor de personas ajenas al interlocutor, las composiciones Aristaenet. I 2 y I 4, pues en la primera el interlocutor es el protagonista y en la segunda forma parte de la pareja de protagonistas.

${ }^{57} \mathrm{La}$ presencia de apóstrofes asi lo sugiere (cf. por ejemplo Aristaenet. I 16, I 18), aunque también los encontramos en las cartas. 
expresión que haga referencia a su naturaleza epistolar ${ }^{58}$. Ya Lesky ${ }^{59}$ nos recuerda que en muchas de esas cartas lo único que mantiene la ficción epistolar es la presencia del nombre del remitente y destinatario.

6.4. Ciertamente la presencia de dos interlocutores es indiscutible en muchas cartas ${ }^{60} \mathrm{e}$ incluso en un par de ellas encontramos insertada una narración sobre otros personajes entre los que no se encuentran el remitente y el destinatario (I 13, I 21). En ambas no faltan expresiones que anticipan el relato, que de ese modo no comienza ex abrupto: $\varepsilon \pi \varepsilon i$

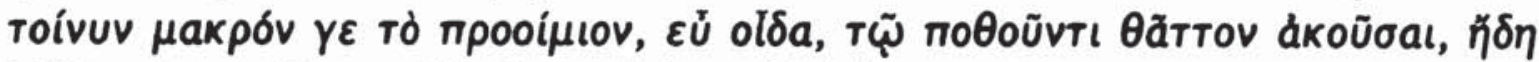

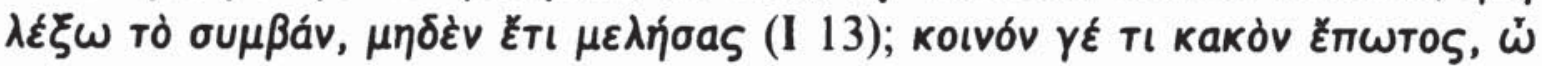

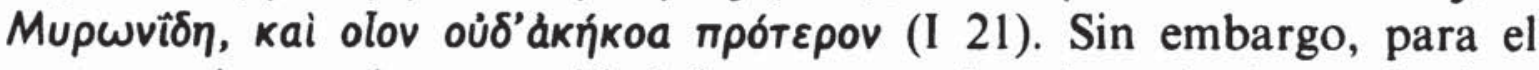
resto no siempre hay necesidad de pensar en la existencia de un destinatario, sino que estaríamos ante lo que los rétores llaman «etopeyas sim-

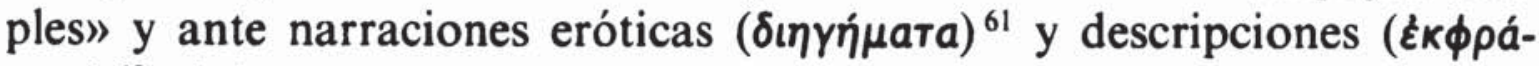
$\sigma \varepsilon ı \varsigma)^{62}$. Así pues, encontramos narraciones y descripciones introducidas (narraciones: I 13, I 15, I 16, I 19, I 21 , I 25 , II 14, II 19 y tal vez I 3; descripciones: I 3, I 11, I 26, II 4, II 10), pero otras se presentan como tales sin más (narraciones: I 4, I 5, I 6, I 7, I 8, I 9, I 10, I 11, I 22 , I 27 , II 4, II 7, II 18, II 20, II 22, y tal vez I 2; descripciones: I 1 y tal vez I 26). Seguramente la existencia de las primeras llevó a quienes reunieron las cartas a aceptar como tales las otras ${ }^{63}$.

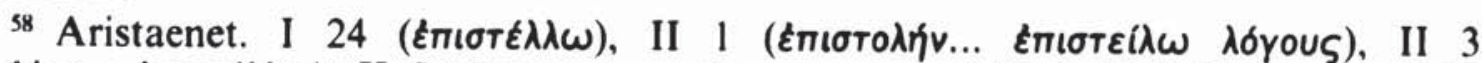

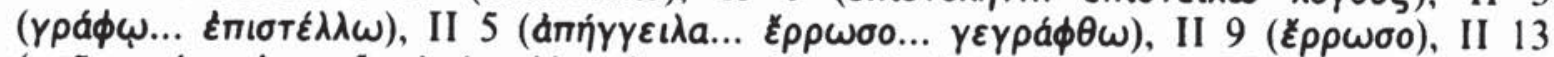

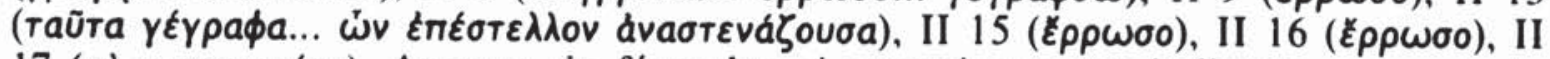

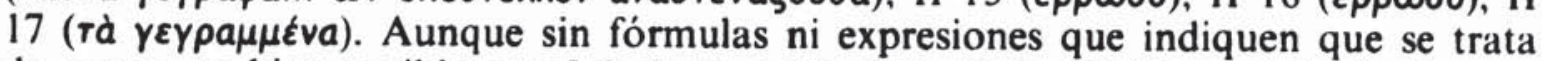
de cartas, es bien posible que I 3, I 17, I 28, II 2, II 6 y II 21 también lo fueran, al menos por lo que se deduce del contexto.

${ }^{59}$ Op. cit. p. 48.

${ }^{60}$ Presencia de dos interlocutores más o menos definidos en Aristaenet. I 3, I 8 , I 13, I 16, I 17, I 18, I 19, I 21, I 23, I 24, I 25, I 28, II 1, II 2, II 3, II 5, II 6, II 9, II 13, II 14, II 15, II 16, II 17, II 19, II 21 , y tal vez I 1 y I 26 . Posibles «etopeyas simples": I 2, II 8, II 11, II 12, y tal vez I 4, I 12.

${ }^{61}$ Sobre la narración y sus tipos, asi como sobre la importancia de dicho ejercicio en el origen de la novela, véase E. Rohde, Der Griechische Roman und seine Vorläufer, Leipzig 1914 (reimpr. Hildesheim 1960), 602 ss. Sobre la inclusión de otros

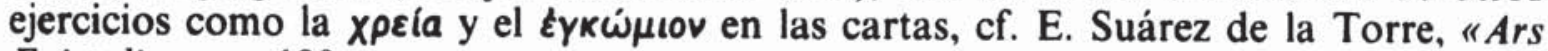
Epistolica», p. 190.

${ }^{62}$ Véase Rohde, op. cit., 335 ss.

${ }^{63}$ Zanetto lleva a cabo una clasificación parecida, usando como criterio el grado de involucración de los personajes del encabezamiento en el desarrollo de la acción tal y como se presenta en la carta (art. cit., p. 196). Según este mismo autor, Aristéneto revela una mayor libertad en la "gestione dell"intestazione'" así como en la elaboración y organización del material (art. cit., p. 197). La explicación nos parecería acertada de no resultar tan sospechosos los encabezamientos de cartas "mímicas», y no sólo las de Aristéneto. 
6.5. Se hace pues necesario aquí también el estudio de los encabezamientos y el análisis de los nombres del remitente y destinatario para decidir sobre su autenticidad y para dilucidar los criterios empleados tanto en la confección de títulos como en la de nombres.

6.5.1. Varias de las cartas carecen de título (I 2, II 6 y I 1, de no

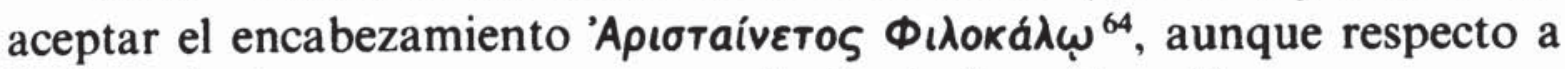
II 6 puede darse por seguro como destinatario a Formión.

6.5.2. Los encabezamientos de las cartas no parecen proceder de la mano del autor y con frecuencia los resúmenes que, en su edición, Hercher ${ }^{65}$ relega como ajenos a la mano de Aristéneto, resultan títulos más apropiados a la naturaleza real de las composiciones, al tiempo que nos recuerdan expresiones introductorias de algunos progymnasmata (cf. por

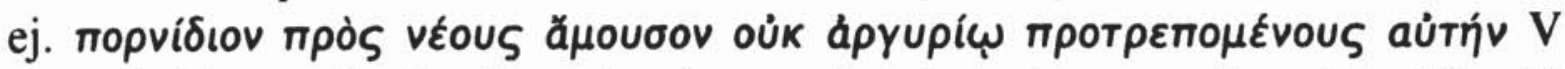

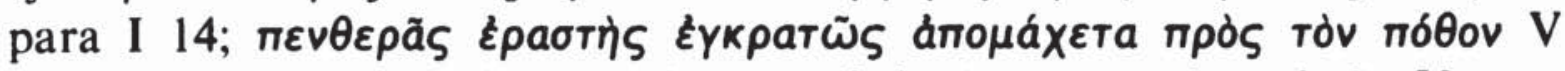

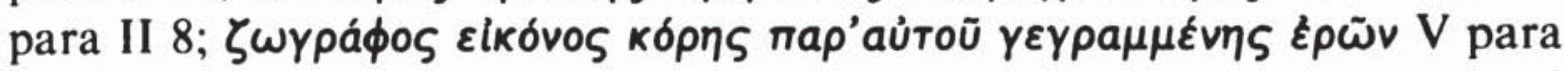
II 10) ${ }^{66}$. Hay que recordar además que esos argumentos aparecen en el único manuscrito, el Vindobonensis, sobre el cual, según Lesky ${ }^{67}$, reposa toda la historia del texto de Aristéneto. Parecen, con todo, haber sido escritos con posterioridad y confeccionados a partir de los propios textos ${ }^{69}$; es decir, concediéndoles a los personajes una naturaleza genérica que, a decir verdad, no siempre tienen.

6.5.3. No son pocos, sin embargo, los interlocutores y personajes cuyos nombres aparecen en el cuerpo de carta; sus nombres por esa misma razón están fuera de toda duda ${ }^{70}$. Dichos nombres son mucho menos llamativos que los presentes en los encabezamientos de las cartes pero ausentes del cuerpo ${ }^{71}$. Así es, del cuerpo de texto están ausentes muchos de los nombres de personajes reales de la tradición literaria, no son tan abundantes los compuestos y creaciones, y en la mayoría de los casos nos encontramos con nombres procedentes de la comedia.

${ }^{64}$ Cf. Arnott, art. cit., p. 291 ss.

65 R. Hercher, Epistolographi Graeci, París 1873, xxi: «Argumenta epistolarum, qualia in codice praefiguntur, ut alienissima ab Aristaeneto in adnotationem relegavi. A ceteris codicis verbis diductis literis distinxi").

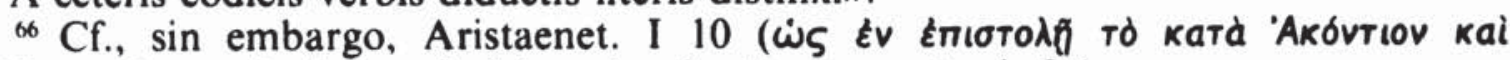

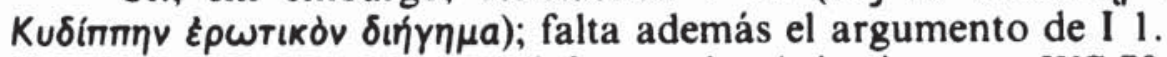

${ }^{67}$ A. Lesky, «Zur Ueberlieferung des Aristainetos», WS 70, 1957, pp. 219-231.

${ }^{68}$ Cf. Mazal, op. cit. p. VIII.

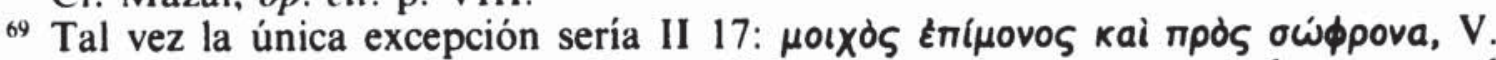

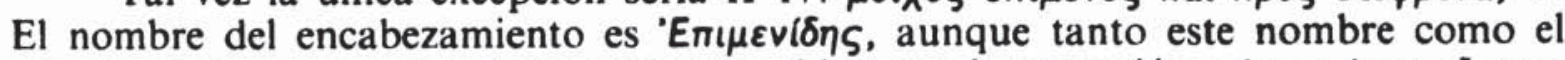
adjetivo $\varepsilon n i ́ \mu \varepsilon v o \zeta$ pueden haber sido sugeridos por la expresión $\mu \varepsilon x \rho \iota$ Tívos, $\dot{\omega} \mu \varepsilon t-$

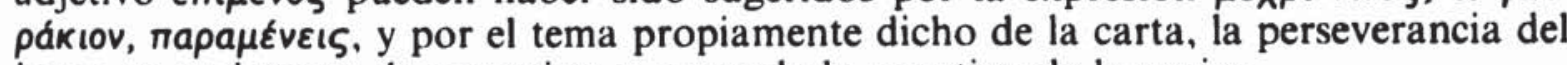
joven en su intento de conquista a pesar de la negativa de la mujer.

${ }^{70}$ Cf. infra Apéndice II) 4 A).

${ }^{7}$ Cf. infra Apéndice II) 4 B). 
6.5.4. Respecto a los nombres presentes en el género epistolográfico, recuerda Arnott ${ }^{72}$ que existen reglas que conciernen a la denominación de los remitentes y destinatarios ficticios. Según este autor son admitidos tres tipos: 1) nombres reales del pasado histórico y literario, «in order to add a spurious touch of verisimilitude to the nostalgic evocation of a more classical past». 2) nombres de los personajes de la Comedia Media y Nueva. 3) nombres inventados para la ocasión de acuerdo con la naturaleza del personaje o de la situación del remitente o destinatario. Aunque en términos generales, y con las debidas reservas respecto a los que no aparecen en cuerpo de carta, estamos de acuerdo con tal afirmación, nos parece bastante sorprendente que no se haya prestado atención al lugar en el que los nombres se presentan, sobre todo cuando la naturaleza epistolar de algunas composiciones es puesta en duda por muchos autores y las diferencias entre los nombres de uno y otro grupo son evidentes. Creíamos, pues, necesario el estudio de ambos grupos por separado y, como hemos hecho con Alcifrón, la comparación posterior usando como punto de referencia los nombres «auténticos", es decir, los presentes en el cuerpo de carta. De dicho estudio hemos obtenido los resultados que a continuación se detallan.

6.5.5. Algunos de los criterios para la confección y adscripción de nombres de encabezamiento no presentes en el cuerpo de carta son los siguientes:

6.5.5.1. Se emplean los nombres de personajes tomados del cuerpo de la carta o del cuerpo de otra carta. No son pocos los nombres que, sin aparecer incluidos en el cuerpo de carta a la que sirven de encabezamiento, sí se incluyen en el cuerpo de otra carta. Dichos nombres se han añadido siguiendo el orden en que las cartas fueron coleccionadas y están actualmente editadas, como prueba el hecho de que todos ellos aparezcan en cartas posteriores a aquellas en las que los encontramos en el cuerpo de texto. Así - citamos en primer lugar la carta donde encontramos el nombre en el cuerpo de carta y a continuación, separado por una barra, la carta donde lo encontramos en el encabezamientoArignota (II 8/II 7); Calíceta (I 12, no como nombre sino como epíteto)/I 18), Glicera (I 19, I 22/II 3), Melisarion (I 19/II 14), Mírtale (I 3/II 16), Policles (I 13/II 7). Como vemos, ese orden de anterior/posterior se da siempre. ¿No es mucha casualidad?

6.5.5.2. Igualmente son frecuentes nombres que hacen alusión al contenido de la carta ${ }^{73}$. Así ocurre con Filoplátano, Cirtión y Dictis,

72 G. Arnott, YClS 27, 1982, pp. 291-294.

${ }^{73}$ Sobre la procedencia de algunos de los nombres empleados ver A. Lesky, op. cit., p. 139, Arnott, YClS 27, 1982, pp. 306 y 317, y Zanetto, art. cit. Particularmen- 
Equepolo y Melesipo, Acestodoro, etc. ${ }^{74}$ Ciertamente, también dentro del cuerpo de carta el autor muestra su gusto por los juegos de palabras con los nombres y por el empleo de nombres parlantes, pero allí nombre y descripción aparecen prácticamente contiguos, como si la presencia de la alusión sólo se justificara por la proximidad del nombre; $y$, además, dichos nombres se aplican de modo directo al personaje al que se refiere la situación alusiva - así sucede con nombres como Limona, Panaceo, Eutíquides, entre otros ${ }^{75}$-, frente a aquellos otros en los que

te frecuentes son las coincidencias con Luciano y Alcifrón. Muchos otros nombres proceden de historiadores.

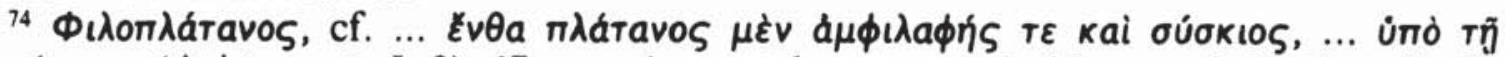

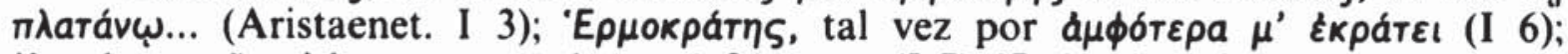

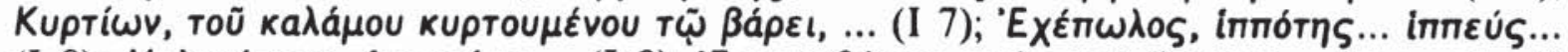

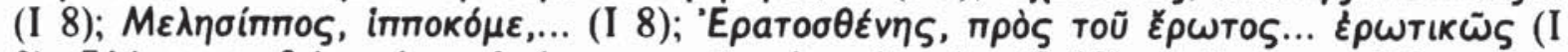

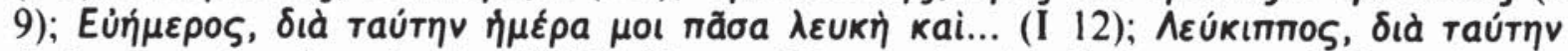

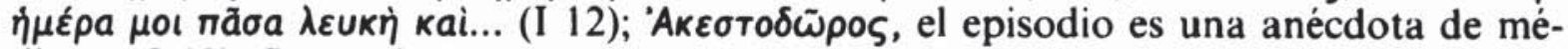

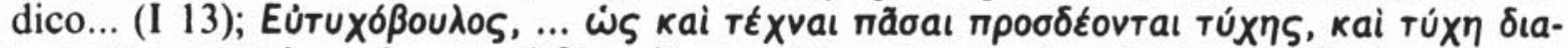

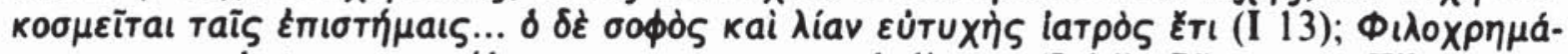

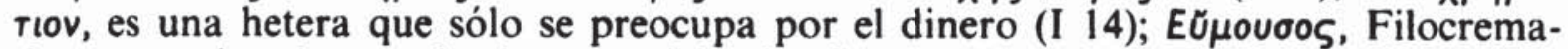
tion aconseja a los muchachos que dejen las flautas, liras o cantos (I 14); 'Aфpoסíios,

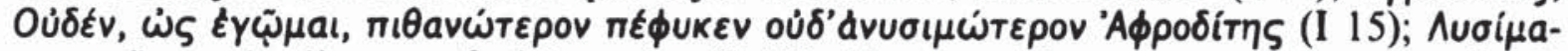

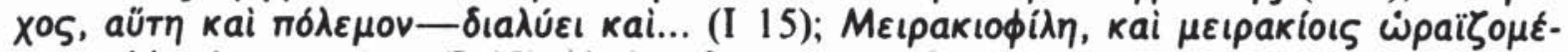

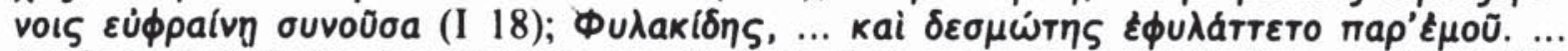

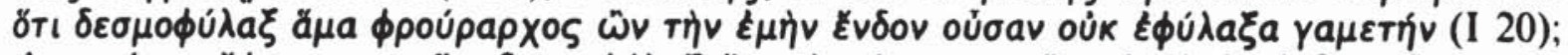

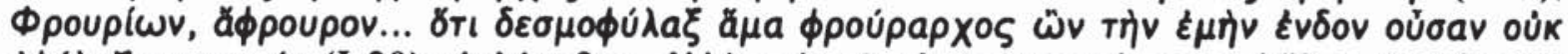

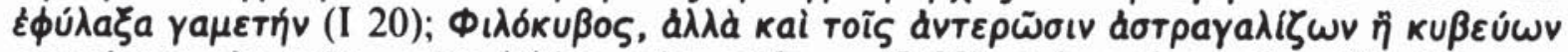

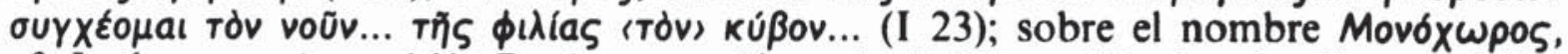

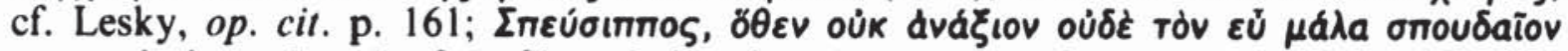

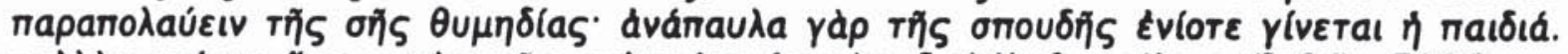

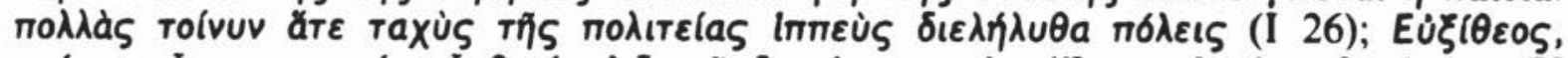

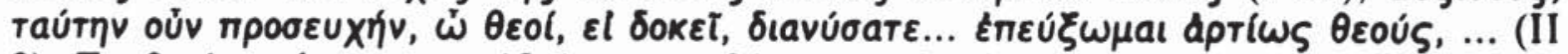

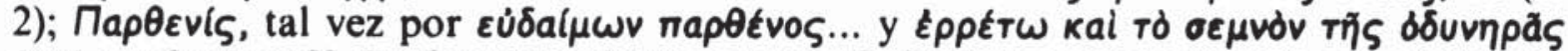

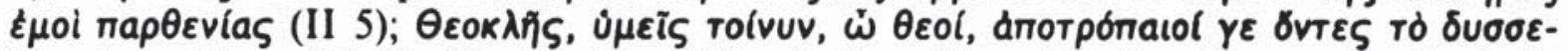

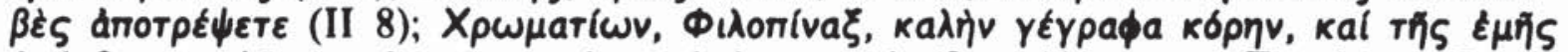

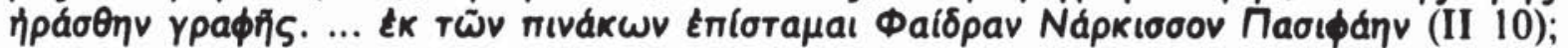

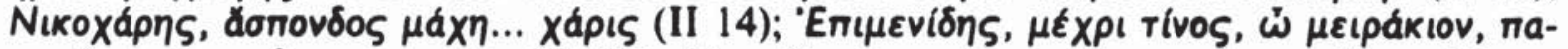

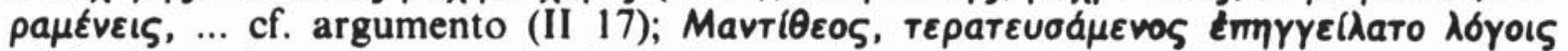

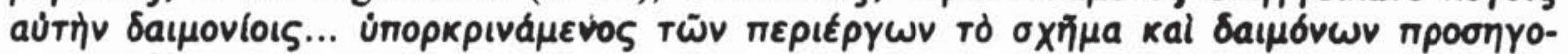

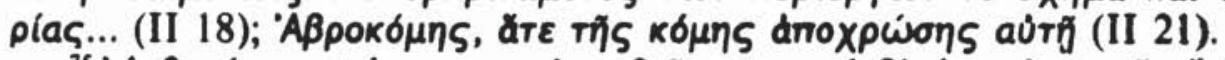

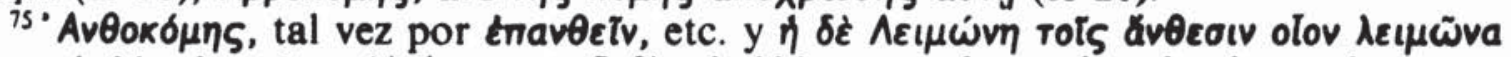

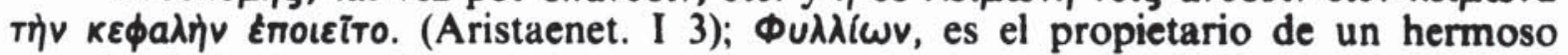

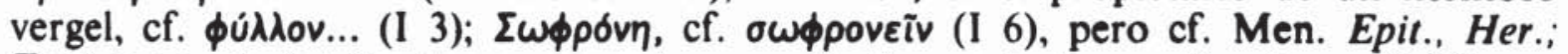

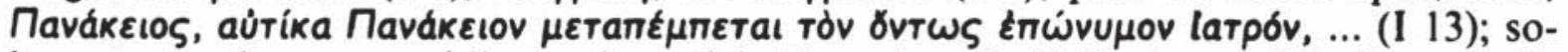

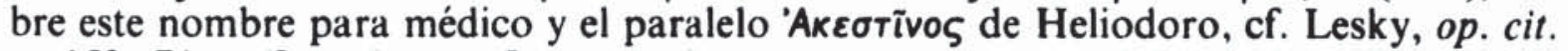

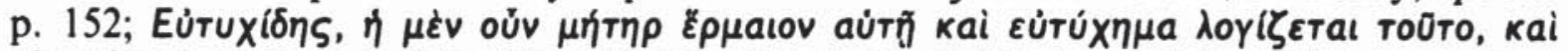

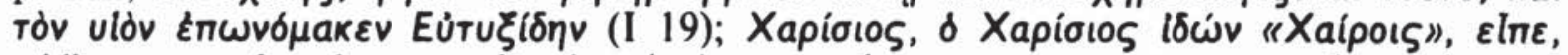

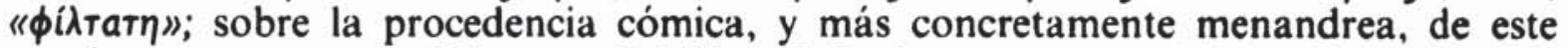

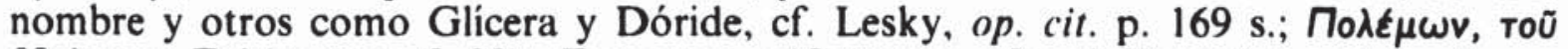

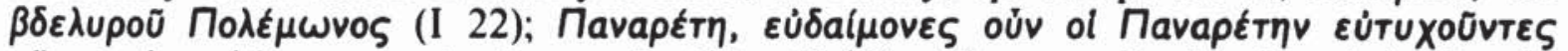

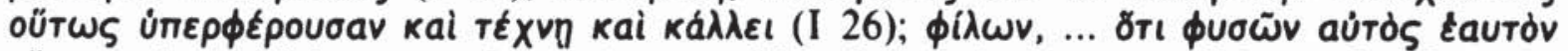
оїєтаı $\mu$ 
los narradores de una historia no propia reciben nombres que más bien corresponderian a los propios protagonistas de las historias ${ }^{76} \mathrm{o}$ cuando el nombre atribuido a un protagonista convendría mejor a otro ${ }^{77}$. De lo que se deduce que quienes añadieron los encabezamientos se sirvieron de técnicas de composición similares a las del propio autor, aunque no completamente iguales.

6.5.5.3. Asimismo encontramos en los encabezamientos nombres de epistológrafos como Luciano, Alcifrón, Eliano, Filóstrato, o nombres de famosos poetas, oradores o artistas, nombres que nunca cita Aristéneto en el cuerpo de la carta ${ }^{78}$.

6.5.5.4. Algunas veces los autores han procurado crear parejas de remitente-destinatario más o menos armónicas ${ }^{79}$. Muy frecuentes son, por otra parte, los nombres compuestos con $\phi i \lambda \circ \varsigma^{80}$, alvé $\omega^{81}, \beta \circ u \lambda \eta^{82}$, entre otros.

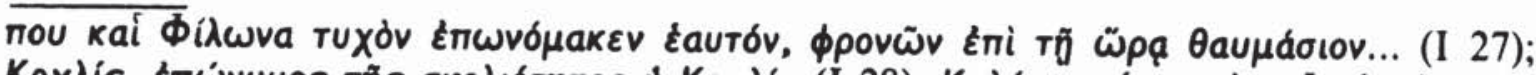

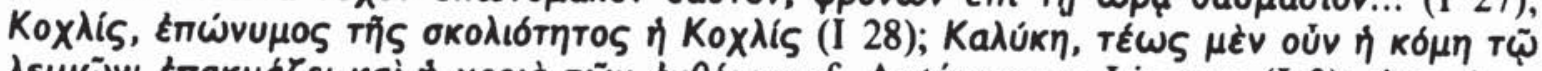

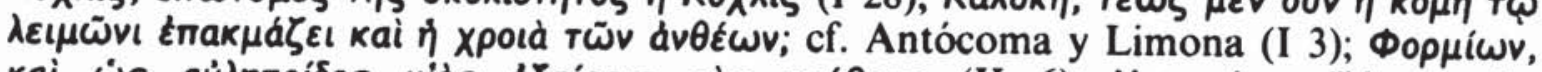

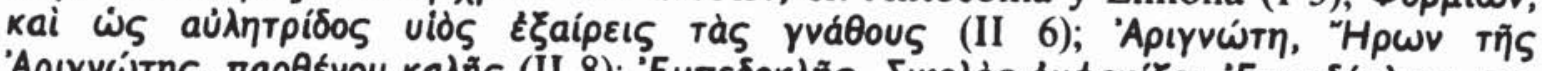

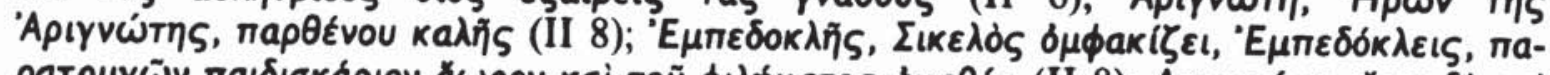

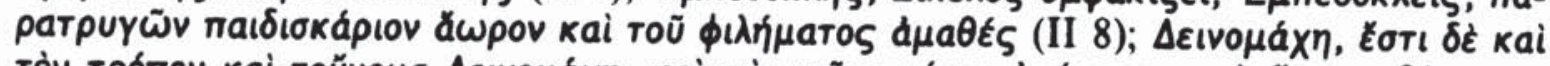

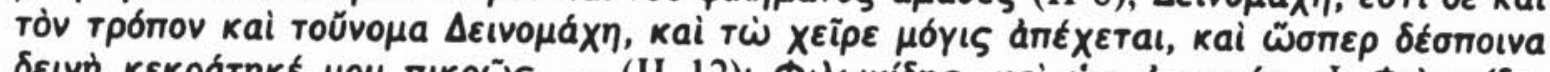

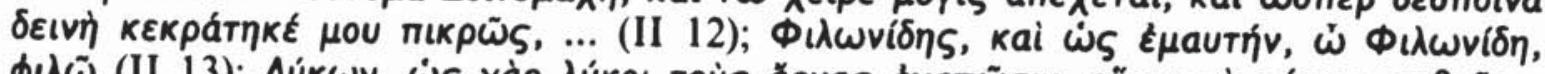

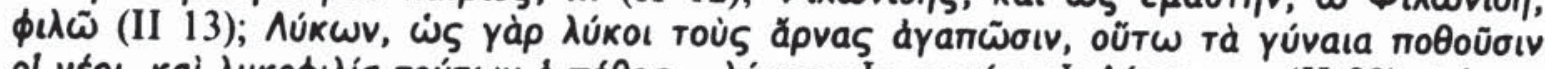

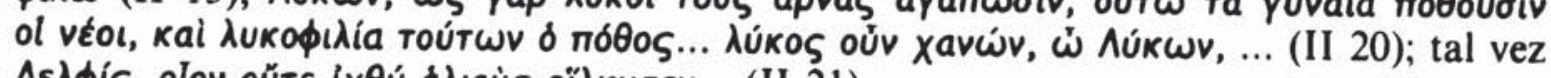

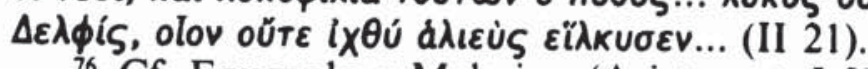

${ }_{76}$ Cf. Equepolo y Melesipo (Aristaenet. I 8), Acestodoro (I 13), Lisímaco (I 15), Mantíteo (II 18). El primero de los ejemplos resulta muy ilustrativo. Por los nombres del título podria entenderse que un jinete se dirige a un mozo de caballerizas, pero realmente es el mozo quien habla al jinete. Ha podido confundir a los tituladores el hecho de que el mozo cuenta a lo largo de su intervención cómo el jinete se dirigió a él después de oírle un comentario sobre su persona.

77 Por ej. Aristaenet. I 15, donde el destinatario de la carta recibe el nombre de Lisímaco. Dicho nombre debe aplicarse mejor a Eros, el verdadero protagonista de la historia, pues es "Amor» quien consigue poner fin a las hostilidades entre dos pueblos. La trasposición afecta igualmente al nombre del remitente Afrodisio. Cf. también Filócalo (Aristaenet. I 1), Leucipo (I 12), Frurión (I 20), Filócubo (I 23), Cromatión (II 10), Abrócomas (II 21) y tal vez Parténide (II 5).

${ }^{78}$ Para el caso de Luciano y Alcifrón, cf. Aristaenet. I 5 y I 22. Sobre el nombre de Eliano, véase Leone, art. cit., pp. 43-44.

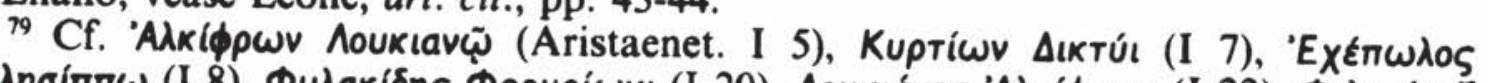

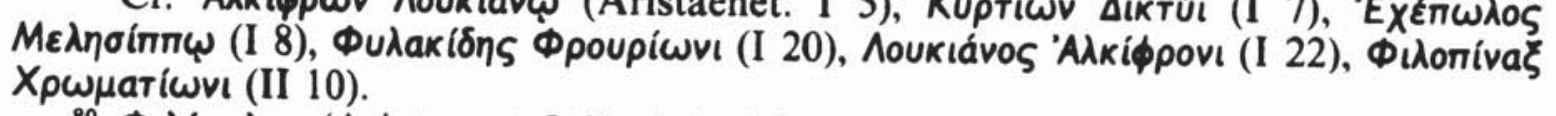

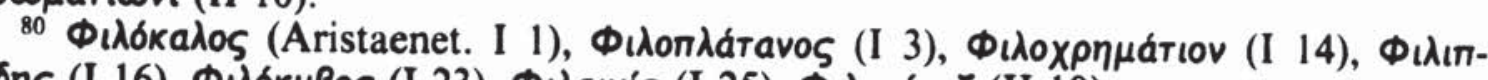

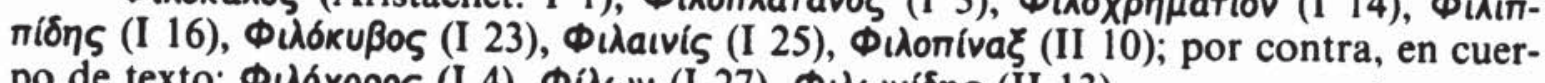

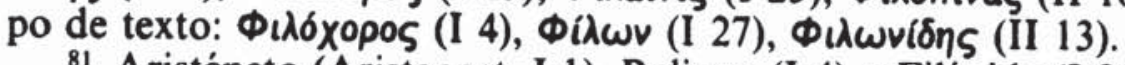

${ }^{81}$ Aristéneto (Aristaenet. I 1), Polieno (I 4) y Filénide (I 25), aunque en el último caso parece tratarse de un préstamo de Luciano, Diálogos de meretrices VI 1 . Los dos primeros no son mencionados en el cuerpo de carta. El nombre Aristéneto describe bien la tarea que lleva a cabo, el elogio de la belleza de Laide. Nombres que 


\section{Teofilacto}

7.1. Teofilacto ${ }^{83}$ es un autor del siglo vil d.C. que compuso bajo el

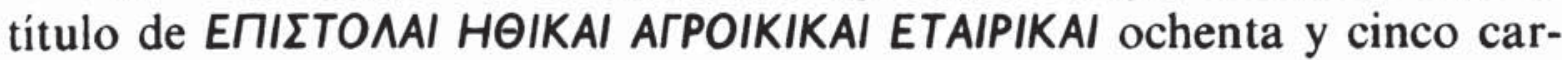
tas de naturaleza etopéyica ${ }^{84}$. Las cartas aparecen ordenadas por ternas compuestas por una carta de índole moral, otra de campesino y otra de heteras, $\mathrm{y}$ así sucesivamente ${ }^{85}$.

7.2. Entre esas ochenta y cinco cartas también hallamos composiciones que por su forma, estructura y contenido se corresponden mejor con «etopeyas simples», es decir, con soliloquios o monólogos del personaje protagonista. En Teofilacto, Ep. 2 un pastor cuenta cómo Pan lo castigó con la pérdida de su carnero guía del rebaño por no haberle ofrecido unas primicias; en Ep. 17 un campesino se queja del fallo de Leucipo en favor de Sóstrato y en contra suya, y lamenta que el dinero pueda más que la propia Justicia; en Ep. 24 una enamorada dice estar buscando desesperadamente a su amante y muestra su irritación ante la sospecha de que se encuentre con otra, amenazando con convertirse en una Medea o una Fedra; en Ep. 27 un campesino decide emigrar del Ática ante la poca fertilidad de la tierra y la enemistad que mantiene con un general; en Ep. 35 un campesino afirma que va a pleitear con un tal Ticanias, a quien prestó un arado y no se lo ha devuelto, y quien, además, tampoco le prestó a su vez, como había prometido, un buey; en Ep. 41 un comerciante que deja la ciudad para dirigirse al campo, lamenta las dificultades que también allí encuentra $y$, finalmente, decide suicidarse; en Ep. 45 un amante se queja de no ser correspondido por igual y llega a dudar de la naturaleza divina de los Amorcillos; en Ep. 60 una hetera reprocha a los viejos sus críticas al amor, cuando el Amor ha vencido a la Filosofia; en Ep. 71 un campesino se queja de tener que dedicarse a la guerra; en $E p .80$ un campesino cuya cosecha ha sido dañada por el Noto dice que va a hacerse soldado.

cuentan con apıroros en la primera parte del compuesto son Aristómenes (I 21), Aristarco (II 4), Aristobulo (II 20).

${ }^{82}$ Euticobulo (Aristaenet. I 13), Eubúlides (II 12), Aristobulo (II 20), todos en encabezamiento y haciendo referencia, al menos en los dos primeros casos, al papel de consejeros representado por los personajes.

${ }^{83}$ Para Teofilacto hemos utilizado la edición de G. Zanetto, Theophylacti Simocatae Epistulae, Leipzig 1985, aunque también hemos consultado la de Hercher, op. cit. LXXXII-LXXXV y pp. 763-786.

${ }^{84}$ El término HOIKAl del título debe traducirse por "morales", y con él se hace referencia a las composiciones que no presentan caracteres de campesino o heteras.

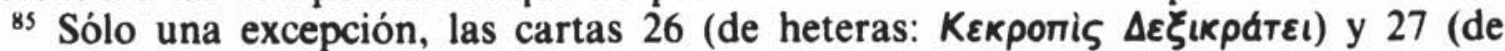

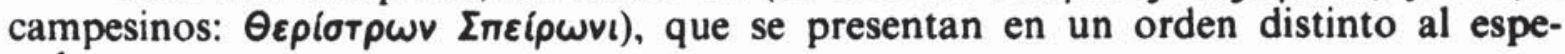
rado. 
7.3. La mayoría de las cartas entra dentro de nuestra clasificación bajo los epígrafes de "etopeyas dobles» ${ }^{86}$ y probables cartas; Ep. 49 es una carta segura; también lo son algunas misivas de invitación ( $E p .29$ y 44), peticiones de ayuda o de utensilios (Ep. 59 y 74), o alguna composición con referencia a un envío anterior (Ep. 20); en muchas la distancia entre los personajes revela su naturaleza epistolar $(E p .5,9,12$, 18 y tal vez 14); de hecho la mayoría de las cartas de campesinos está dirigida a un vecino; también en aquellas en que se trata de calmar la cólera de alguien es razonable pensar que nos hallamos ante una carta (Ep. 4, 10, 28).

7.4. Por supuesto, también algunos de los nombres presentes en los encabezamientos son sospechosos de falta de autenticidad ${ }^{87}$. Entre las cartas morales es frecuente encontrar los nombres de famosos filósofos como Sócrates, Platón y Diógenes en el papel de remitentes. Pues bien, en $E p$. 40, por ej., las palabras del remitente y destinatario no parecen corresponderse con las que se hubieran dirigido Sócrates y Platón, que son los nombres presentes en el encabezamiento. Ningún Leónidas, que sepamos, arrebató a Platón un campo, ni ningún Filipo le quitó su anillo. Tampoco podemos referir la anédota del eunuco lidio de Ep. 43 a Diógenes el cínico. Entre las de campesinos, lo mismo puede decirse de $E p$. 17, cuyo encabezamiento reza $\Lambda o ́ \phi \omega \nu ~ \Pi \varepsilon \delta ı a ́ \delta ı$. El nombre de ambos ha sido confeccionado a partir de una colina que sirve de límmite a un

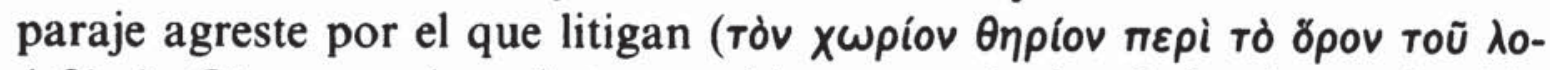
$\phi ı \delta i o u)$. Otros nombres interpretables a partir de algún dato ofrecido por el texto, pero, a nuestro juicio, desafortunados, serían Ortigón (Ep. 38) y Calamón $(E p .50)^{88}$. Entre las cartas de heteras las $E p .54,66$ y 81 nos aportan más ejemplos que confirman nuestra hipótesis. Aunque en $E p .54$ una mujer reprocha a su amado el abandono y olvido, sería difícil aceptar, como sugiere el encabezamiento, que los personajes implicados en una carta de naturaleza étaıııкŕ sean Medea y Jasón. Lo mismo puede decirse de Ep. 66. Los nombres presentes en el encabezamiento son Peito e Hipólito, pero a la razón antes argüida, se añade

${ }^{86}$ Cf. Ep. 38 entre un padre y un hijo.

${ }^{87}$ Para los nombres presentes en el cuerpo de carta y encabezamiento en Teofilacto, véase Apéndice II) 5.A) y B).

${ }^{88}$ Calamón es un campesino que recomienda a otro que se marche si le preocupan más la política y los procesos que el campo. El nombre tal vez se deba a la ex-

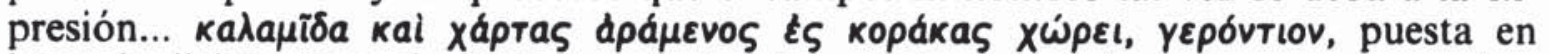
boca de dicho personaje. Ortigón, "codorniz», es el nombre de un joven, cuyo padre, el campesino Tetigón, le regaña por haber espantado las perdices (тoù $\pi \varepsilon \rho \delta$ ikaৎ) a causa de su aspecto extraño y comportamiento propio de un borracho y le amenaza con despeñarse junto con él si no vuelve a reunir a las perdices. 
ahora la mención del nombre de Rodoclea, con lo que puede quedar descartado como destinatario Hipólito. Sin embargo, quizá el ejemplo más claro es $E p$. 81, dirigida, según el encabezamiento, por Leandro a Calícomo. Pero la carta tanto puede ir dirigida a una mujer como a un hombre, y la comparación con Dánae podría sugerir lo primero ${ }^{89}$. Pues

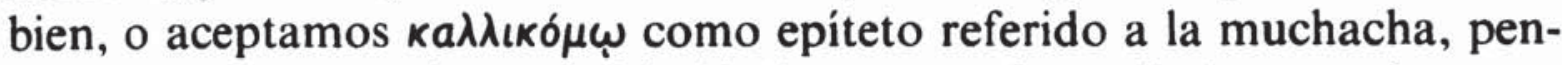

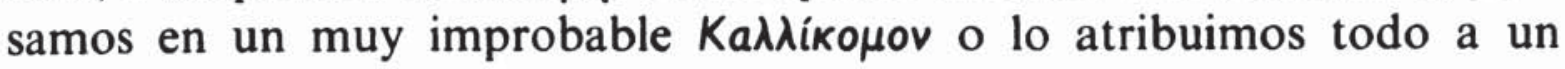
error de asignación.

7.5. No son pocos los nombres que aparecen en el cuerpo de texto y en el encabezamiento de otra carta distinta. A continuación ofrecemos la lista completa y hemos marcado con tres asteriscos cuando ambos nombres pertenecen al mismo grupo de cartas (morales, de campesinos, de heteras) y representan caracteres similares; con dos asteriscos cuando se incluye en el mismo grupo pero el carácter es claramente distinto; con un solo asterisco cuando el carácter es similar pero se incluye en distinto grupo; cuando no existen coincidencias no hemos puesto marca. En resumen:

\begin{tabular}{|c|c|}
\hline$* * *$ & $=$ grupo $=$ carácter \\
\hline$* *$ & $=$ grupo $\neq$ carácter \\
\hline & $\neq$ grupo $=$ carácter \\
\hline & $\neq$ \\
\hline
\end{tabular}

Antístenes (Ep. 28/22**), Axíoco (Ep. 70/25**), Coridón (Ep. 44/ $\left.80^{* * *}\right)$, Cipasirón $\left(E p .71 / 11^{* * *}\right)$, Crisipa (Ep. 84/51***), Crisógona (Ep. 42/12***), Diógenes (Ep. 60/19*, 43*, 46*, 76*), Gorgias (Ep. 65, 69/16), Laide (Ep. 60/24**, 69**), Hermágoras (Ep. 13/4, 10), Leónidas (Ep. 40/49**), Mirónides (Ep. 14,77/35***), Rodoclea (Ep. 66/51***), Sócrates (Ep. 58/40*, 52*, 64*, 82*), Sosípatro (Ep. 10,84/25*** respecto a 10 y $72^{* * *}$ respecto a 84$)$, Sóstrato $(E p$. 17/61), Telesila (Ep. 72/ $\left.24^{* * *}\right)$, Terpandro (Ep. 7/48), Tetis $\left(E p .39 / 33^{* * *}\right)^{90}$. Las conclusiones que puedan extraerse de estos datos serán sólo orientativas, pues el propio Teofilacto presenta en el cuerpo de carta un mismo nombre para persunaje de distinto grupo y carácter, como ocurre con Sosípatro, personaje al que trata de convencer alguien para que cese en su irritación por haberle cambiado la fortuna en Ep. 10; y enamorado de Antusa, a quien alguien recomienda que no se preocupe por ello en Ep. 84. Con todo se observa que la coincidencia de nombres que aparecen dentro

${ }^{89}$ En Filóstrato, el sexo del personaje con el que se compara coincide prácticamente siempre con el del personaje comparado.

${ }_{90}$ La pareja Tetis y Galatea que encontramos en el cuerpo de carta se repite como encabezamiento en Ep. 33. 
del cuerpo de carta implica también un mayor parecido de carácter entre los personajes a los que designan.

7.6. Al igual que ocurre en Aristéneto, también en Teofilacto encontramos otros ejercicios de preparación incluidos en las cartas, aunque en este último autor siempre introducidos. Así en $E p$. 15 hallamos una écfrasis y en Ep. 34 y 61 sendos $\mu \tilde{\theta} \theta 0$.

\section{Heroidas de Ovidio}

8.1. En el caso de las Heroidas de Ovidio ${ }^{91}$, obra sobre cuya naturaleza y novedad es mucho lo discutido ${ }^{92}$, con frecuencia el carácter epistolar es aclarado con versos añadidos preferentemente al comienzo por una parte de la tradición manuscrita, versos que además sirven para presentar los nombres del remitente y destinatario ${ }^{93}$. Evidentemente tales versos no pertenecerían al autor y son fruto de una transmisión manuscrita extrañada por el comienzo ex abrupto, in medias res, en estilo directo con apóstrofes ${ }^{94} \mathrm{o}$ exclamaciones, de dichas composiciones. A este respecto conviene recordar la opinión de Quintiliano sobre el estilo de las suasorias. Quintiliano recrimina el uso de comienzos abrup-

91 Para Ovidio hemos seguido la edición de $\mathrm{H}$. Bornecque, Ovide. Héroïdes, París 1928, y hemos prestado atención a las de G. Showerman, Ovid. Heroids and Amores, Loeb 1914 y F. Moya del Baño, Ovidio. Heroidas, Madrid 1986.

${ }^{92}$ H. Jakobson, Ovid's Heroides, Princeton 1974, p. 338 ss.; A. F. Sabot, "Les 'Héroïdes' d'Ovide: Préciosité, Rhétorique et Poésie», en $A N R W$ II, 31.4, W. Haase, ed., Berlin 1981, p. 2574 y 2590 ss.

${ }_{93}$ Ou. epist. 2; epist. 5 / Nympha suo Paridi, quamuis suus esse recuset, / Mittit ab Idaeis uerba legenda iugis. / Perlegis? an coniunx prohibet noua? Perlege; non est /Ista Mycenaea littera facta manu.] (los vv. 1-4 son secluidos por Bornecque, mientras que Showerman y Moya del Baño sólo secluyen los vv. 1-2; en epist. 7 [Accipe, Dardanide, moriturae carmen Elissae; / Quae legis, a nobis ultima uerba legis.] ante un comienzo... Sic ubi fata uocant, udis abiectus in herbis Bornecque y Moya del Baño introducen secluidos ambos versos; en epist. 8 Moya del Baño introduce secluidos [ Alloquor Hermione nuper fratremque uirumque, / Nunc fratrem; nomen coniugis alter habet.] (vv. 1-2) ante un comienzo... Pyrrhus Achillides, animosus imagine patris; en epist. 9 Moya del Baño incluye un dístico en el que la propia carta habla: [Mittor ad Alciden a coniuge conscia mentis / Littera si coniunx Deianira tua est.]; en epist. 12 Moya del Baño introduce secluidos [Exul inops contempta nouo Medea marito / Dicit; an a regnis tempora nulla uacant?] ante el comienzo... At tibi Colchorum, memini, regina uacaui; epist. 13 [Mittit et optat amans, quo mittitur, ire salutem / Haemonis Haemonio Laodamia uiro.] vv. 1-2, Bornecque secluye; Moya del Baño y Showerman los aceptan sin secluir. Bornecque también secluye los versos 163-164, aceptados por Moya del Baño y Showerman, Vltima mandato claudetur epistula paruo. / Si tibi cura mei, sit tibi cura tui.].

${ }^{94}$ Cf. Sabot, art. cit., p. 2576, n. 65. 
tos y llenos de exclamaciones, y recomienda abandonar esa costumbre, al parecer muy extendida entre los rétores (inst. III 8, 58-60).

8.2. Los añadidos a que hemos hecho referencia proceden en concreto del codex Etonensis (Bibl. Coll. Bl. 6,5, siglo XI) y del Escurialensis g III 1 (siglo XV). Del primero dice Bornecque: "C'est au service du même genre, pour les six premières Héroïdes et pour les vers 1-159 de la septième que l'on peut attendre de l'Etonensis, transcrit d'un original très inférieur à celui du Guelferbytanus, et, en outre, gâté par les corrections d'un grammarien médiocre" ${ }^{95}$. Moya del Baño, en cambio, le concede algún valor, entre otras razones porque "trae los dísticos iniciales, ausentes en otros, de epist. 5, 6 y $7{ }^{96}{ }^{96}$, también ésta es una de las particularidades del Escurialensis g III $1(\Delta)$, que incluye los comienzos de epist. 5, 8, 9, 11 y 12; de dicho codex Bornecque no hace siquiera mención.

8.3. Sin entrar en la discusión sobre la autenticidad de cada una de las cartas ${ }^{97}$ y teniendo por otra parte en cuenta el hecho de que el propio autor se refiere a su obra con el término "Epistola" cuando en $E l$ arte de amar (III 345 s.) recomienda su recitado, creemos que Ovidio escribió etopeyas en forma de carta, en las que ciertamente no faltan influencias de otros géneros ${ }^{98}$. Muchas de estas composiciones son cartas propiamente dichas desde un punto de vista formal ${ }^{99}$. Pero en otros casos los apóstrofes a divinidades y rupturas en la narración, así como la ausencia de fórmulas de salutación, son un indicio de la distancia exis-

${ }^{95}$ Bornecque, op. cit., XIX.

96 Moya del Baño, op. cit., LXVII.

${ }^{97}$ Sobre la discusión acerca de la autenticidad de las cartas, véase Sabot, art. cit., p. 2554 ss.

${ }_{98}$ Véase Jakobson, op. cit.

99 Ovidio, epist. 1: Hanc... mittit / ... rescribas (vv. 1-2), digitis charta notata meis (v. 62); epist. 3: Quam legis, ... littera uenit / .. notata manu. / ... lituras; (vv. 1-3); epist. 4: salutem /Mittit ... / Perlege ... epistula lecta... (vv. 1-3). Fedra no se atreve a dirigirse directamente a Hipólito. Cf. Perlegis; et lacrimas finge uidere meas (vv. 175-176; final); epist. 6: alusión a una posible carta de Jasón: ... epistula / ... missa digna salute fui (vv. 7-8); epist. 10: Quae legis, ... mitto (v. 3); epist. 11: ... scripta lituris, / ... libellus... / ... charta / ... scribentis... (vv. 3-7); epist. 14: Scribere (v. 131); epist. 15 ... litera dextrae, / ... legisses (vv. 1-4). Pero en los versos 53 ss. se dirige a las Nisíades y Ericina; y las expresiones no muy definitorias An riget? et Zephyri uerba caduca ferunt? / Qui mea uerba ferunt, uellem tua uela referrent (vv. 208-209). Safo pide una carta donde Faón le diga que desea estar lejos de ella, vv. 219-220, final; epist. 16: mitto... salutem (v. 1), Perlege (vv. 12-13),... littera... (v. 340); epist. 17: epistula (v. 3). Referencia a epist. 16; epist. 18: leges (v. 4), littera... charta (v. 1520), Litteraque (v. 202), epistula (v. 217, penúltimo verso); epist. 19: missisti uerbis... salutem, / ... missam (vv. 1-2), referencia a Heroidas 18, cf. v. 93; ... littera missa (v. 210, verso final); epist. 20: scribo mittoque rogantia uerba; (v. 35), Scripta... littera... (v. 40), ... littera... (v. 174); epist. 21: legi (v. 3), referido a epist. 20; scribere (v. 22), littera (v. 28), scriptis (v. 214), charta (v. 246). 
tente entre lo que compuso Ovidio y lo que podemos entender por carta ${ }^{100}$. También el contenido de varias de ellas es en gran medida incompatible con el sentido originario de comunicación de la carta ${ }^{101}$.

8.4. No es nuestra intención dudar de la existencia del género. Ovidio las llama cartas y algunas de ellas, aunque no todas, cuentan con expresiones y fórmulas que lo confirman. Pero el hecho es que, cuando tales fórmulas faltan, la composición puede definirse como etopeya y, cuando están presentes, podemos hablar de etopeyas en forma de carta.

8.5. El caso de las Heroidas ha sido traído a colación, de un lado, porque confirma la relación etopeya-carta, y de otro, porque ilustra sobre la manipulación por parte de la transmisión manuscrita de los textos para poner de manifiesto el carácter epistolar que el propio contenido de la obra no presenta.

\section{Conclusión}

9.1. A nuestro juicio, cuando se pusieron de moda las cartas literarias, se llevaron a cabo colecciones de ejercicios de preparación sólidos de la mano de rétores ${ }^{102}$. Junto a las cartas (o etopeyas en forma de carta) encontramos "etopeyas simples» y «dobles» que no presentan dicha forma, narraciones, descripciones, etc. En realidad la diferencia entre una etopeya en forma de carta y otra que no la tuviera radicaría en cualquier caso en alguna alusión a esa naturaleza epistolar, sea de forma directa o a través de una fórmula, sea por la indicación de la imposibilidad de comunicación directa entre los interlocutores; pero en cuanto a lo demás, incluido el modo de ejecución (ambas eran ejecutadas en voz alta ${ }^{103}$ ), no se diferenciarían en absoluto ${ }^{104}$. Sólo plantearían dificultades para su interpretación como cartas las «etopeyas simples», es decir, las no dirigidas a nadie; aquellas en que el interlocutor se dirige a un grupo y aquellas en que la viveza e inmediatez del texto requiririan

100 Sobre este aspecto, véase Moya de Baño, op. cit., XIII, n. 2.

101 Deyanira se dirige a Hércules ya muerto, Penélope escribe a Ulises aunque no conoce su paradero, Ariadna se encuentra en una isla desierta.

${ }^{102}$ En el caso de Eliano y como recuerda Leone «la stessa inscriptio ('Ex Tw̃v

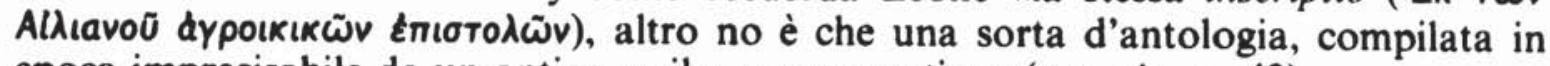
epoca imprecisabile da un antico scriba o grammatico" (art. cit., p. 43).

${ }^{103}$ Cf. Ruiz García, op. cit., p. 137 n. 21.

$104 \mathrm{Sí}$, en cambio, se diferenciarian de las cartas no «miméticas» en cuanto al estilo, como confirma la poca adecuación de las cartas de Alcifrón a la preceptiva epistologrática, cf. R. G. Ussher, "Love Letter, Novel: Alciphron and "Chion'», Hermathena 143, 1987, 99-106. 
un medio de comunicación más directo que el que proporciona una carta. Por otro lado, la frecuente inclusión en cartas de narraciones y descripciones facilitó la desviación de algunos ejemplos «puros» de estos y otros ejercicios hacia las colecciones de cartas. Todo ello explica las peculiaridades de una técnica compositiva como la de Alcifrón en la que los textos se ajustan poco, según E. Ruiz García, a las convenciones del género: ausencia de fórmulas, el hecho de que más que cartas pueda hablarse de escenas y situaciones captadas al vuelo y descritas con cierta vivacidad, mimetización, etc. ${ }^{105}$ No es que el autor entienda o modifique el género de esa forma, sino que, más allá de lo que pueda atribuirse a la innegable influencia de la etopeya sobre la carta, el género se ha visto acrecentado con composiciones etopéyicas y de otro tipo que le son en parte ajenas. Así las cosas, no es de extrañar que el género esté muy vinculado a nombres de sofistas y de rétores famosos o autores muy impregnados de retórica: Alcifrón, Eliano, Filóstrato, Aristéneto, Teofilacto y Ovidio. Por lo demás, no sabemos si los editores y coleccionistas hallaron reunidos estos ejercicios, sea o no como cartas, o si ellos mismos los buscaron y agruparon en un momento en que el género epistolográfico atraía el interés del público.

9.2. En su esfuerzo por presentar esos ejercicios de preparación como cartas o simplimente porque los creían cartas, los editores y coleccionistas añadieron, tal y como se hacía en aquéllas, encabezamientos con los nombres del remitente y el destinatario. Muchos de los nombres se extrajeron del cuerpo de texto y se confeccionaron encabezamientos más o menos seguros, pero otras veces hubo que recurrir a los nombres aparecidos en otras cartas o se confeccionaron nombres de acuerdo con los criterios que se deducían de los encontrados en el texto. Incluso se añadieron encabezamientos a las etopeyas que más dificultades oponían, y a las narraciones y descripciones puras. Un ejemplo de procedimiento paralelo sería la solución de añadir dísticos al comienzo de algunas de las Heroidas de Ovidio, fruto de la dificultad que ofrecian los comienzos ex abrupto de alguna de las composiciones. Esta solución fue la adoptada en algunos de los códices que nos han transmitido el texto. Finalmente, del estudio comparativo entre los nombres de cuerpo de texto y encabezamiento contenidos en las cartas de Alcifrón, Eliano, Filóstrato, Aristéneto ${ }^{106}$ y Teofilacto pueden concluirse diferencias que serian indicativas de distinta paternidad.

105 Ruiz García, op. cit., p. 134 y n. 20, pp. 136-137 y n. 21, p. 160.

106 Aristéneto, en el cuerpo de texto, sólo se sirvió de los nombres utilizados por Alcifrón también en el cuerpo de texto, lo que indica que Aristéneto no leyó los encabezamientos. 
9.3. Somos conscientes de que algunos de nuestros argumentos (aunque no todos) podrían ser utilizados para avalar la autenticidad de los nombres de los encabezamientos. En cualquier caso, si todos ellos han salido de las manos de Alcifrón, Eliano, Filóstrato, Aristéneto y Teofilacto, puede hablarse de mayor independencia en la creación de nombres en un género como el de la carta, y en concreto para los encabezamientos. Esta independencia habría sido facilitada por ser muchos sus personajes genéricos, hablando en terminología retórica; lo que permitía al autor juegos etimológicos en el encabezamiento. Pero, como ya hemos dicho, no somos de esta opinión y creemos que las innovaciones de Alcifrón, Aristéneto y Teofilacto fueron muchas menos que las adiciones posteriores hicieron pensar a estudiosos como Sondag, Bompaire, Lesky y Arnott ${ }^{107}$.

Jesús UReña Bracero

\section{APENDICE}

I) En esta tabla presentamos algunas de las coincidencias entre la teoría retórica epistolar tal y como la resume A. J. Malherbe en "Ancient Epistolary Theorists" (Ohio Journal of Religions Studies, 5, 2, 1977 , p. 15 ss.) y las recomendaciones de los rétores sobre la etopeya:

Definición de la etopeya

A. Letter is one half of a dialogue (Dem. 223), or a surrogate for an actual dialogue (Cic. Ad Fam. XII 30,1).

In it one speaks to an absent friend as though he were present (Cic. Ad Fam. II 4, 1; Sen. 75, 1; Ps. Lib., 2, 58; Jul. Vict.).
La etopeya es un ejercicio dialógico muy útil para las conservaciones; Spengel, II, op. cit. p. 60, 24-26 (Teón).

La etopeya compuesta $(\delta เ \pi \lambda \eta)$ es dirigida a alguien que se imagina presente; $\mathrm{cf}$. Spengel, II, op. cit. p. 15, 24 (Hermógenes).

La etopeya consiste precisamente en tratar de reflejar el $\eta \theta 0$ os de quien habla; cf. por ej. Spengel, II, op. cit. p. 115, 22 ss. (Teón).

${ }^{107}$ Th. Sondag, De nominibus apud Alciphronem propriis, Diss. Bonn 1905, p. 63 ss.; J. Bompaire, Lucien écrivain: imitation et création, París 1958, p. 700; Lesky, op. cit. p. 139 ss., Arnott, art. cit. 


\begin{tabular}{|c|c|}
\hline Estilo epistolar & Estilo de la etopeya \\
\hline a. Letter must be concise. & $\begin{array}{l}\text { La etopeya debe ser breve; Spengel, II, } \\
\text { op. cit. p. } 45,16 \text { (Aftonio). }\end{array}$ \\
\hline $\begin{array}{l}\text { b. Letters must be clear in what they } \\
\text { say. }\end{array}$ & $\begin{array}{l}\text { La etopeya debe ser clara; Spengel, II, } \\
\text { op. cit. p. } 45,16 \text { (Aftonio). }\end{array}$ \\
\hline $\begin{array}{l}\text { c. Letters must be adapted to the cir- } \\
\text { cumstances and mood of their addressees } \\
\text { (Cic. Ad Fam. II 4, 1; 4, 13, 1; Ad Att. } \\
\text { IX 4, 1; Dem. 234; Ps. Dem., proem: } \\
\text { Philostr.; Greg. Naz., 51, 4). }\end{array}$ & $\begin{array}{l}\text { La etopeya también refleja el } \eta \theta 0 \varsigma \text { de } \\
\text { la persona a la que va dirigida; Spengel, } \\
\text { III, op. cit. p. } 489,9-10 \text { (Nicolao). }\end{array}$ \\
\hline $\begin{array}{l}\text { Letters should be written in the most } \\
\text { appropriate style (Cic. Ad Fam. XV 21, } \\
\text { 4; Ps. Lib. 1, 46). }\end{array}$ & $\begin{array}{l}\text { El estilo de la etopeya debe adaptarse } \\
\text { a la situación; Spengel, II, op. cit. p. } 16 \text {, } \\
\text { 7-10 (Hermógenes). }\end{array}$ \\
\hline
\end{tabular}

II) Nombres de encabezamiento ${ }^{108}$ y de cuerpo de carta en Alcifrón, Eliano, Filóstrato, Aristéneto y Teofilacto.

\section{Alcifrón}

A) Nombres que aparecen en cuerpo de carta: 'Andóviov (III 2, 1),

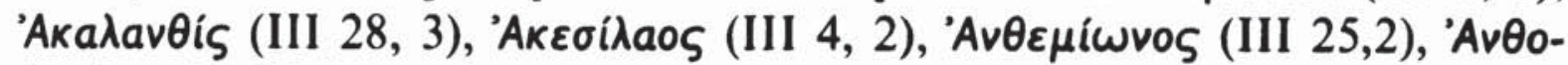

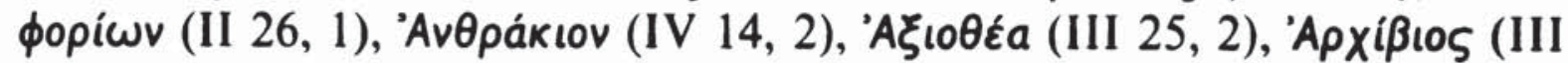

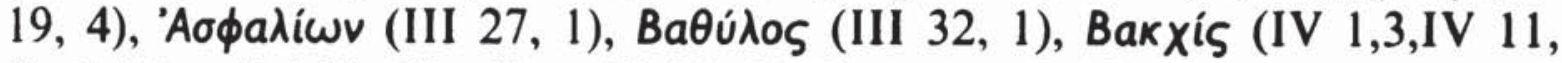

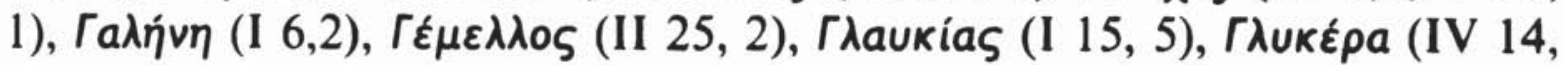

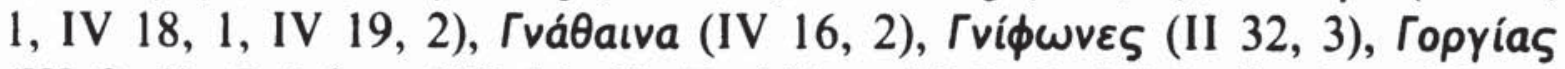

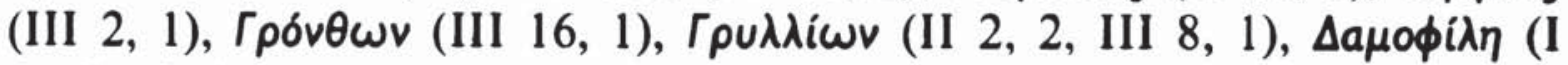

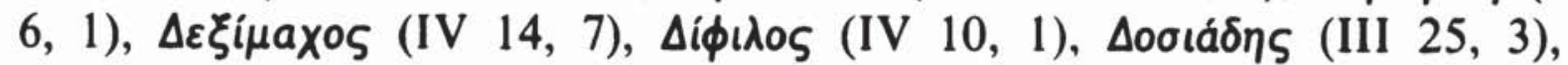

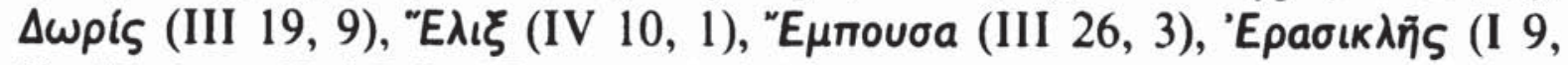

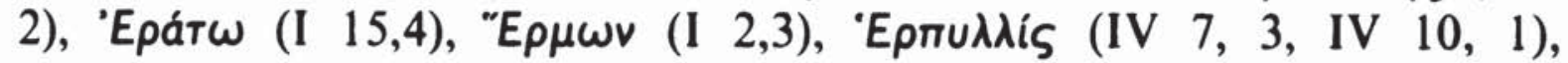

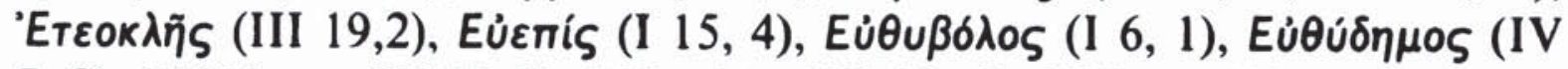

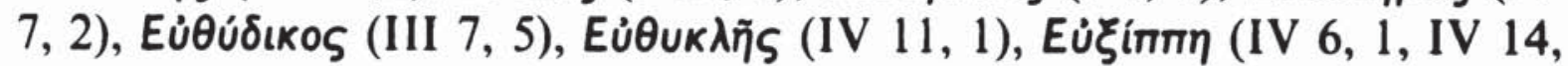

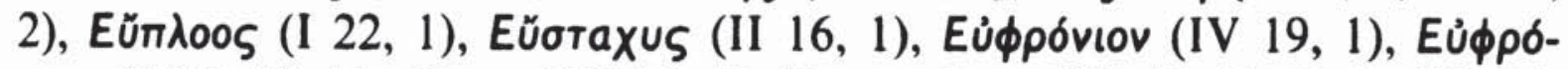

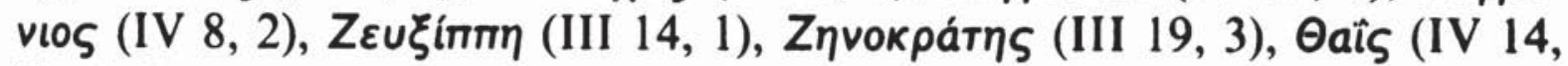

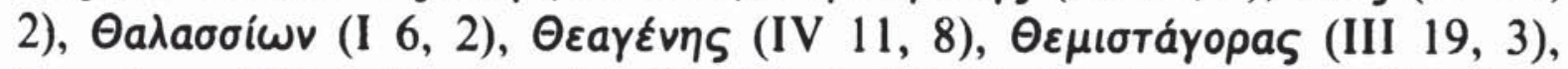

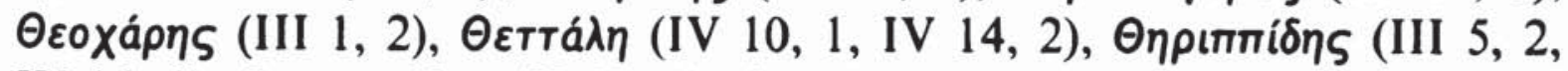

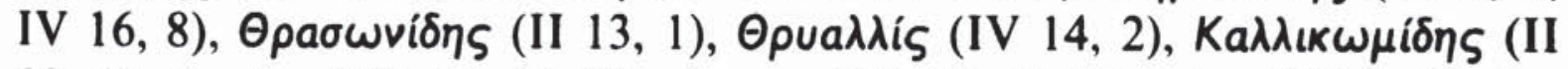

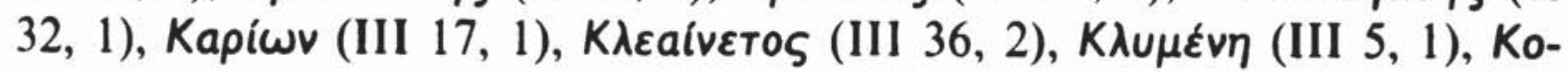

${ }^{108}$ Quedan excluidos los que aun apareciendo en encabezamiento se hallan en el cuerpo de texto de la misma. 


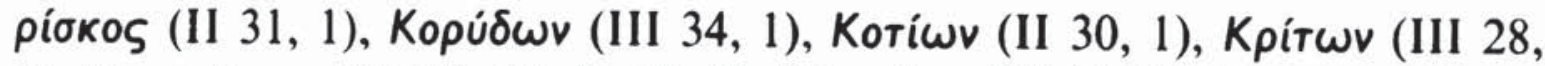

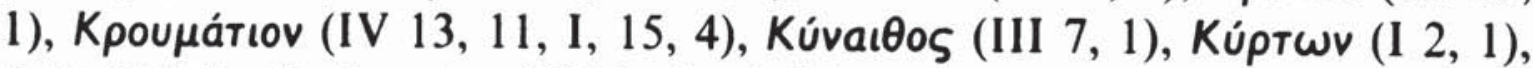

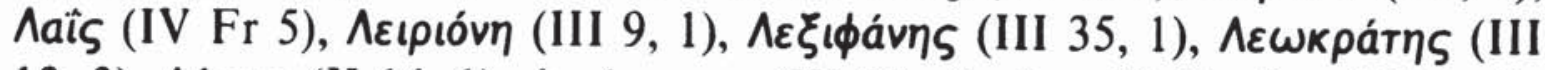

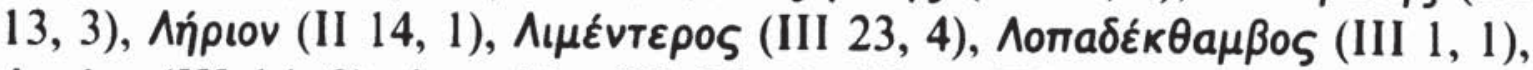

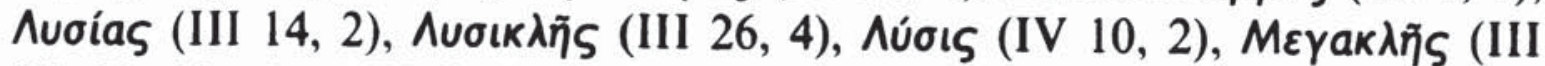

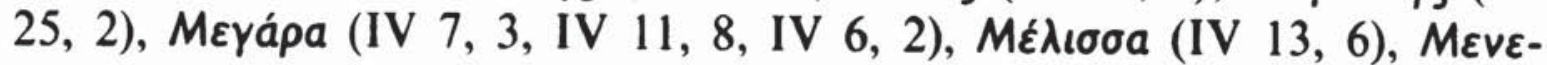

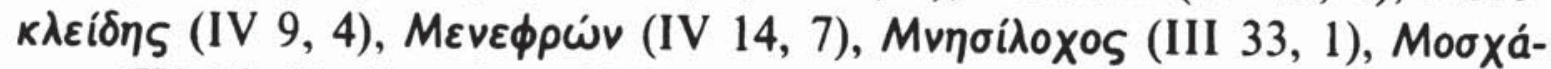
piov (IV 14, 2), Mooxíwv (II 35, 1), Muppivi (IV 14, 2), Neßpís (III 31,

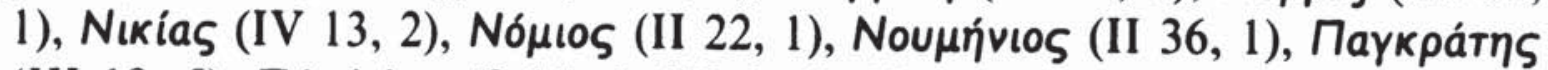

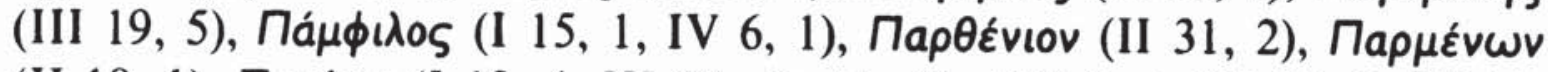

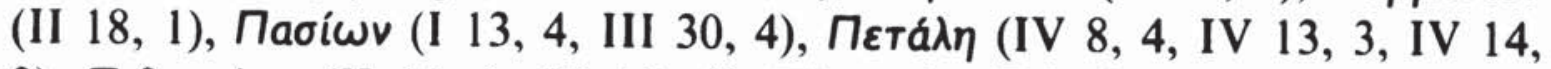

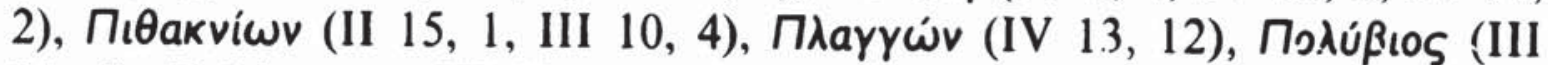

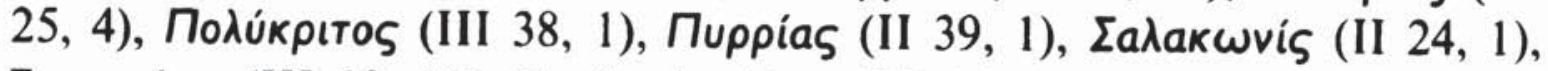

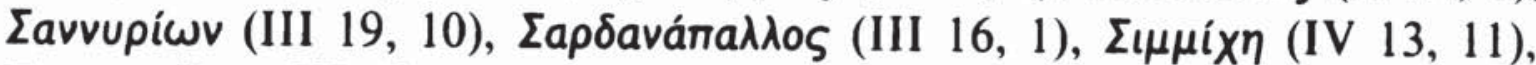

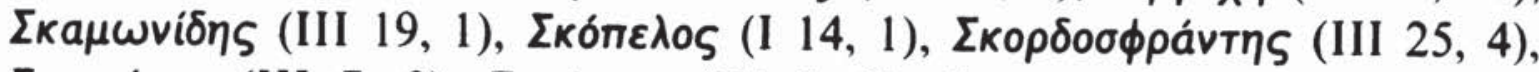

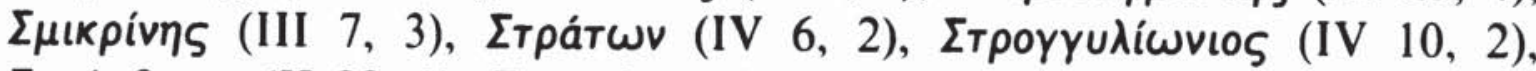

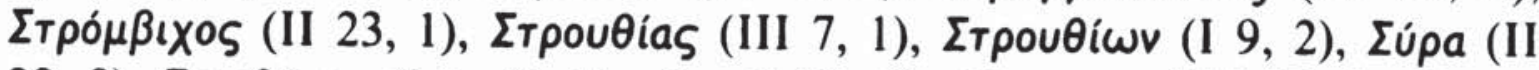

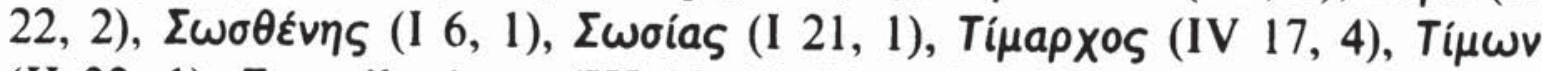

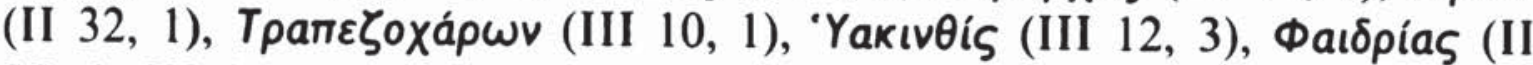

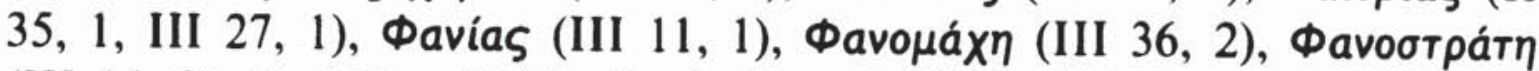

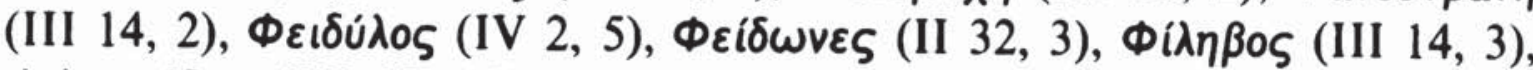

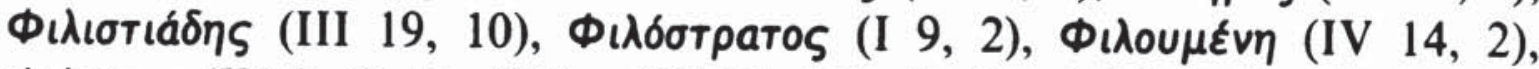

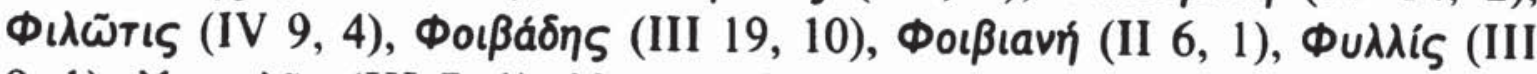

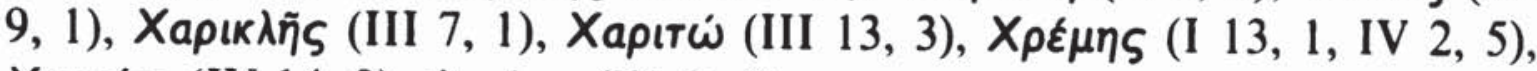

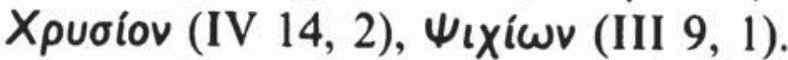

B) Nombres que aparecen en encabezamiento y no en cuerpo de

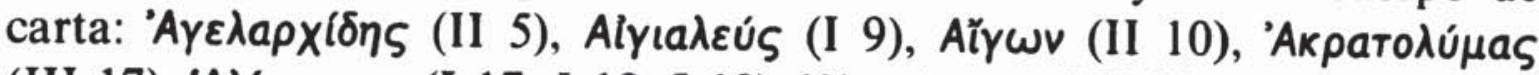

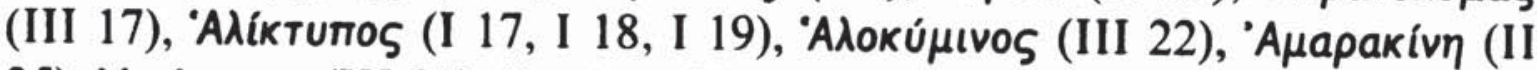

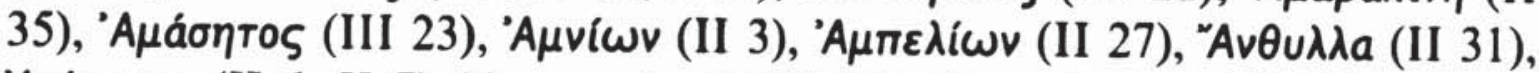

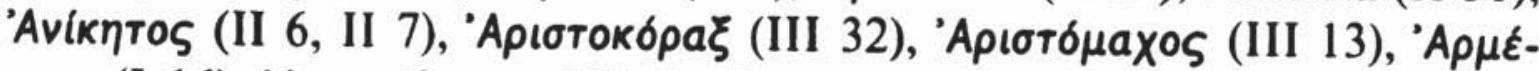

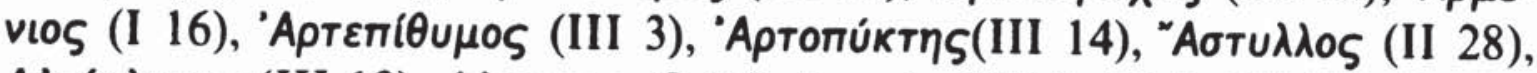

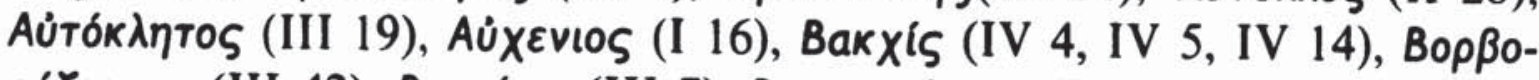

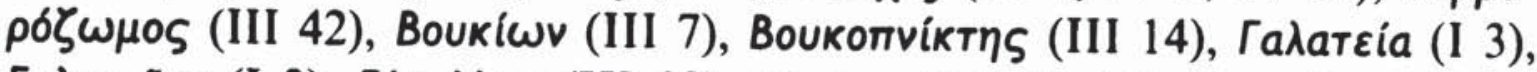

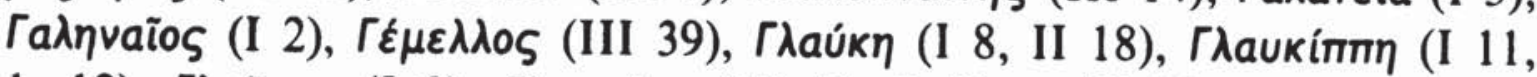

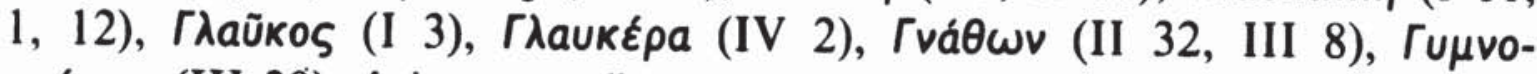

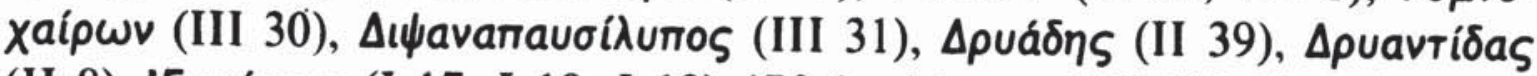

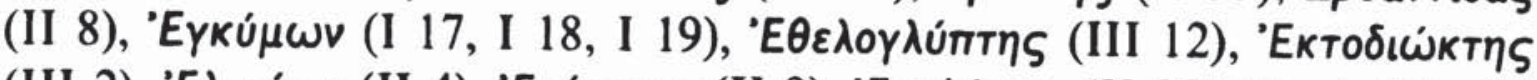

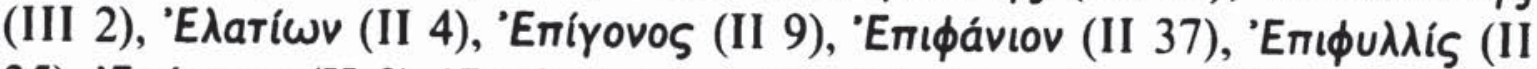

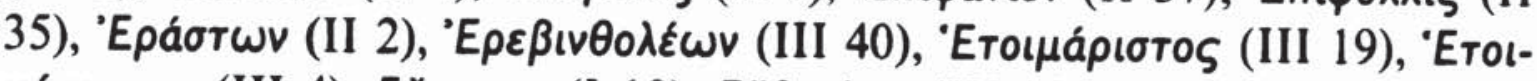

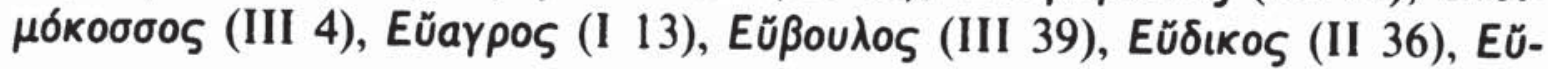




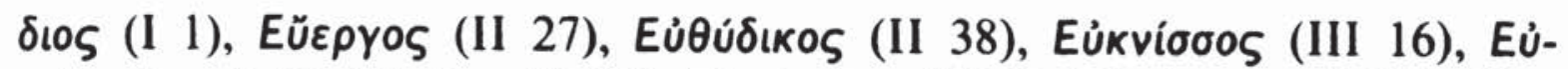

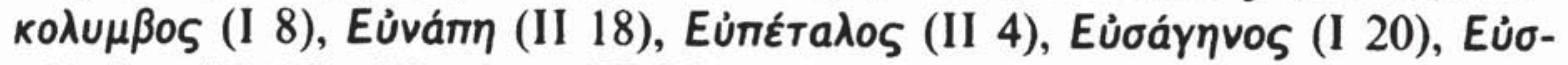

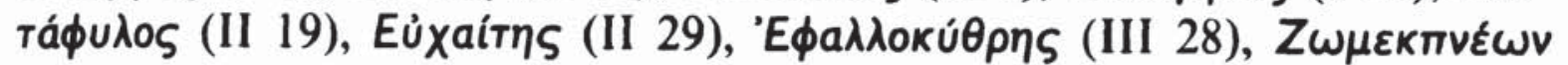

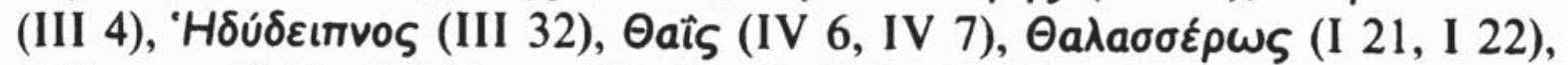

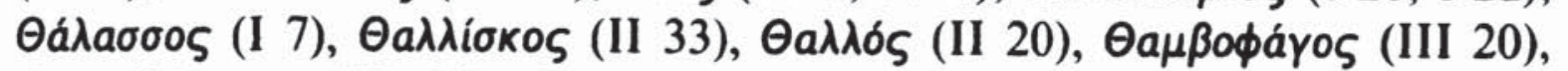

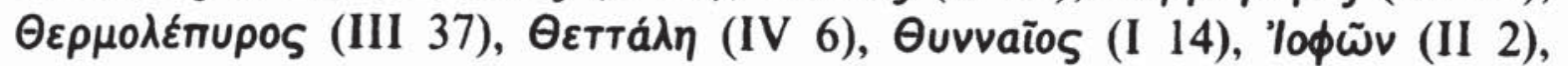

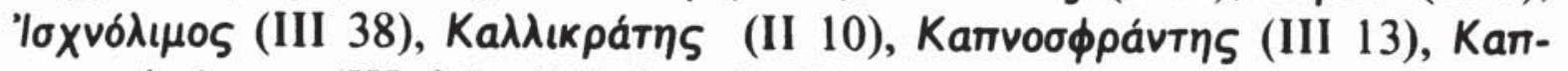

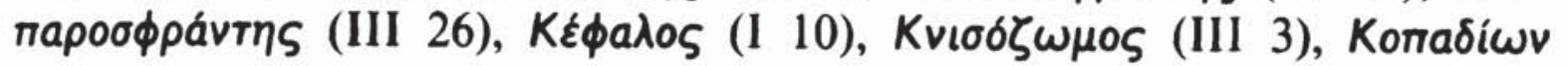

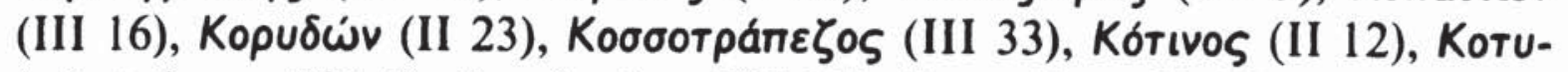

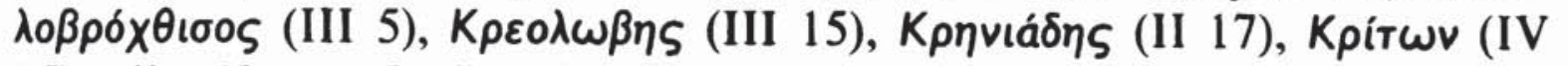

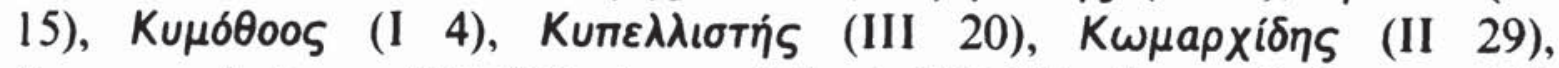

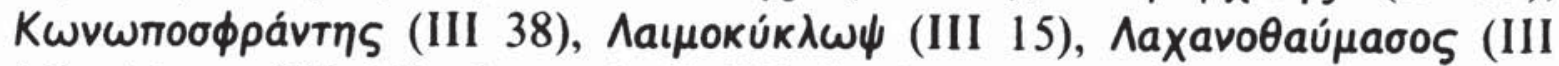

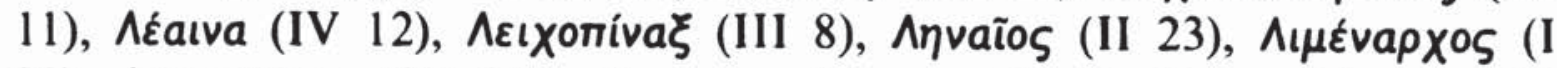

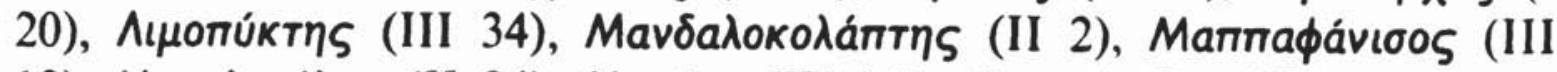

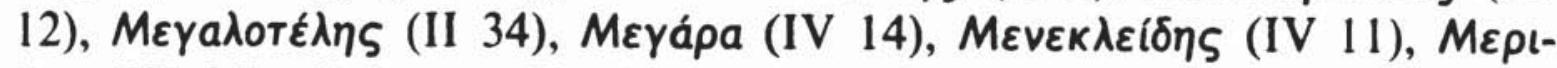

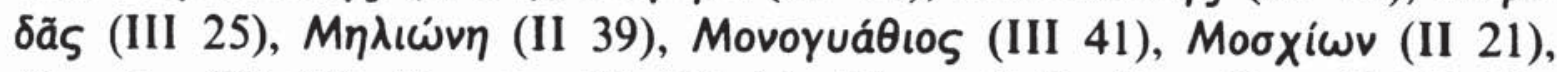

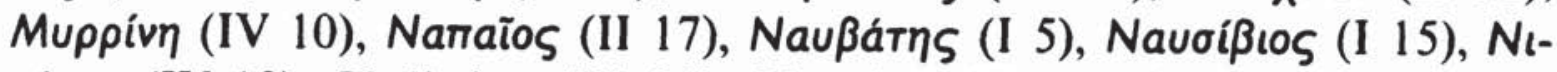

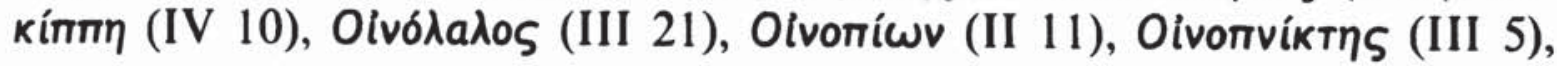

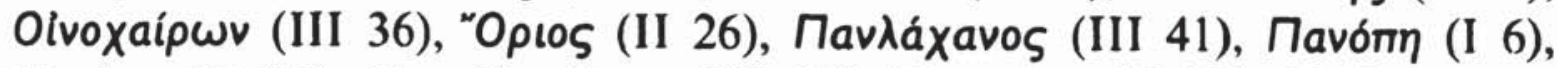

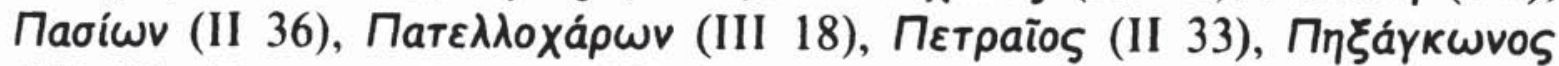

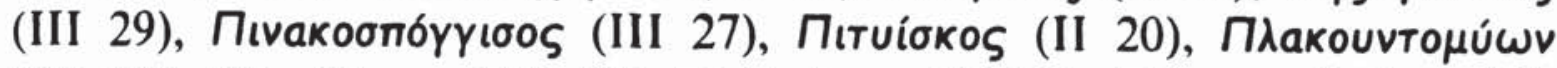

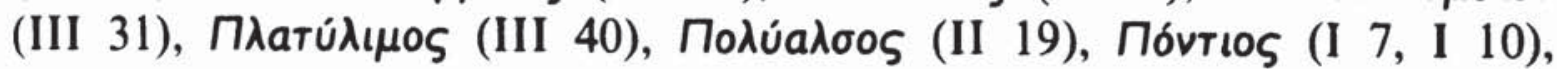

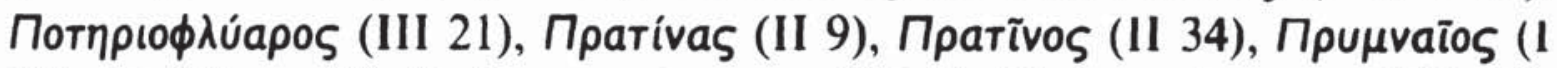

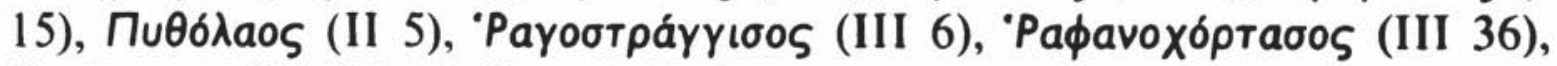

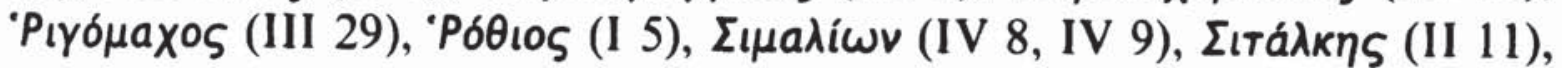

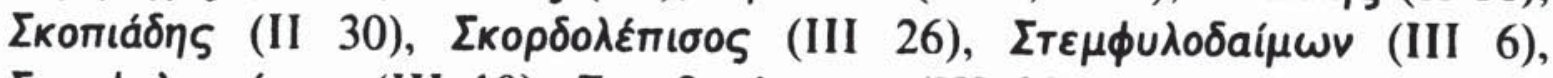

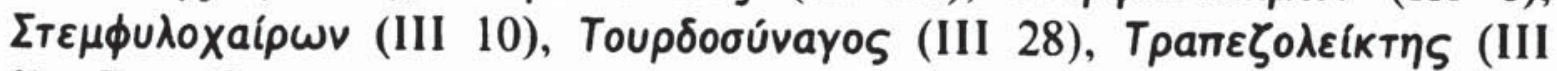

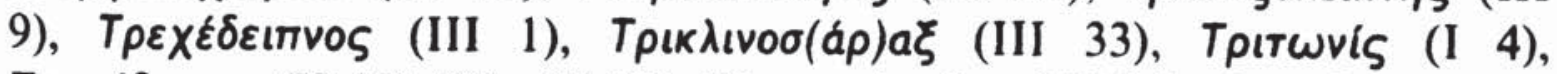

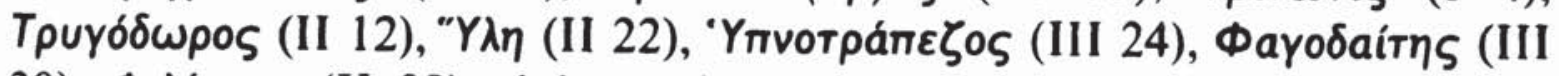

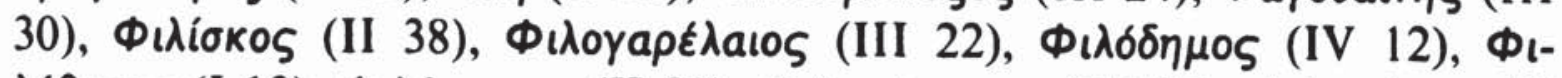

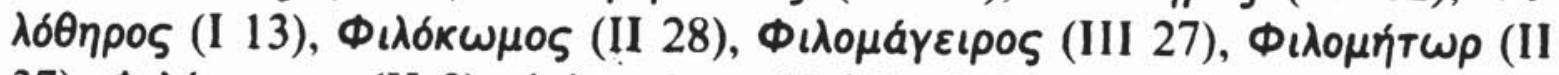

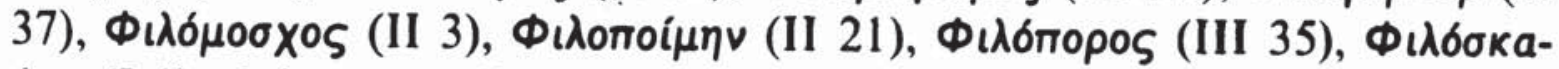

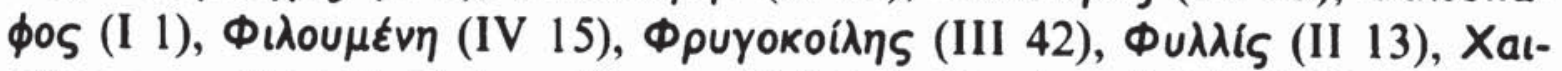

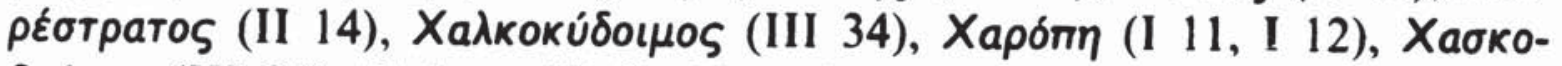

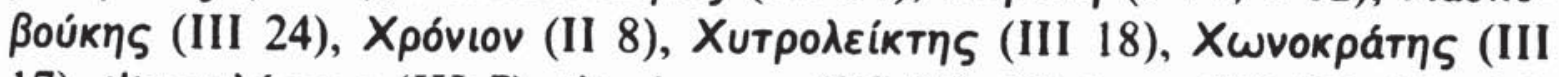

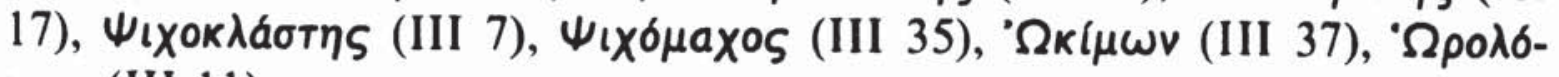
yios (III 11).

2. Eliano

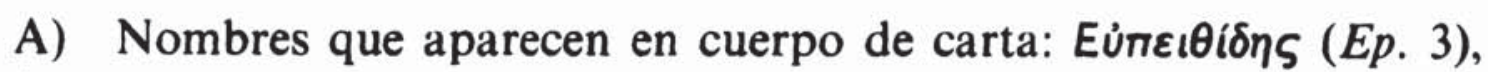

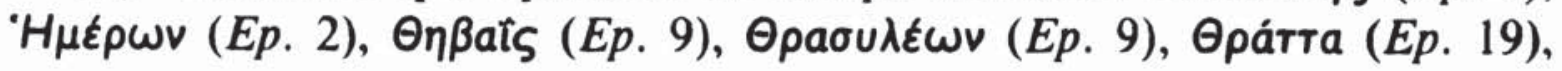




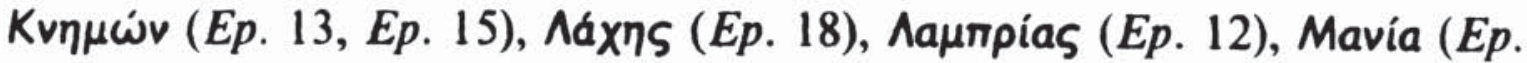

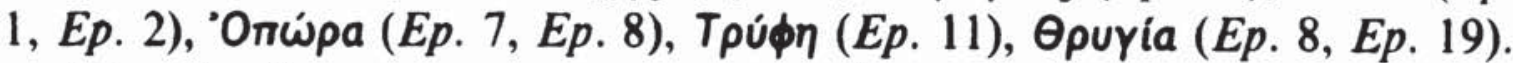

B) Nombres que aparecen en encabezamiento y no en cuerpo de

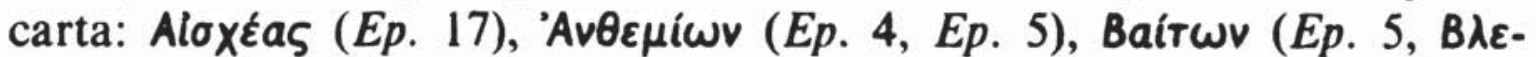

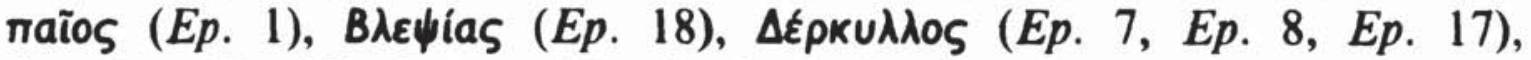

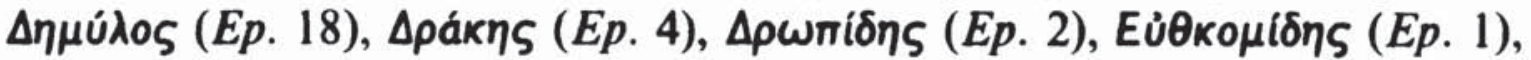

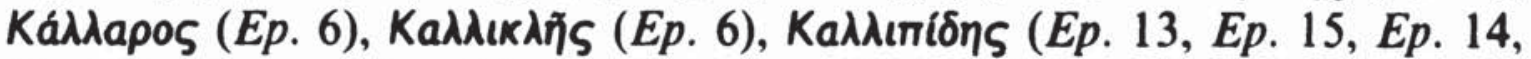

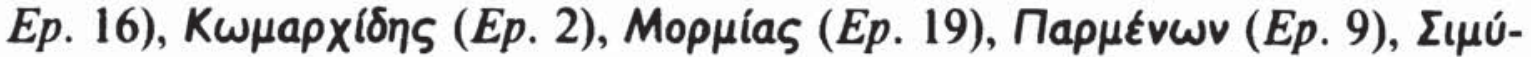

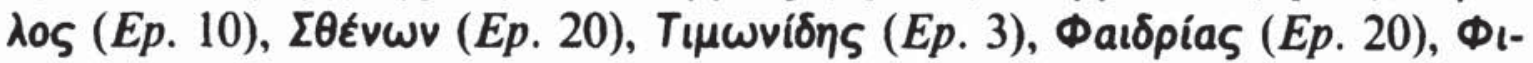

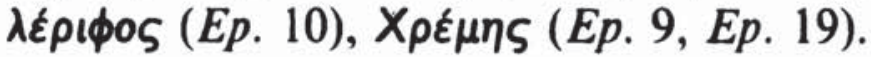

\section{Filóstrato}

A) Nombres que aparecen en cuerpo de carta: 'Apırтayópa (Ep. 22,

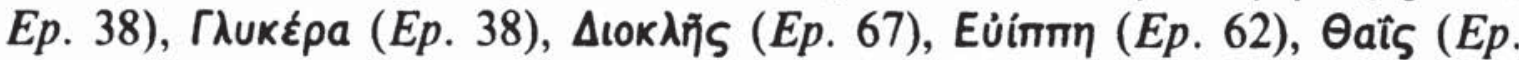

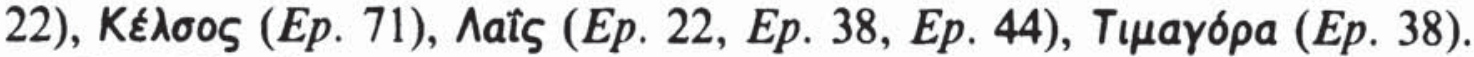

B) Nombres que aparecen en encabezamiento y no en cuerpo de

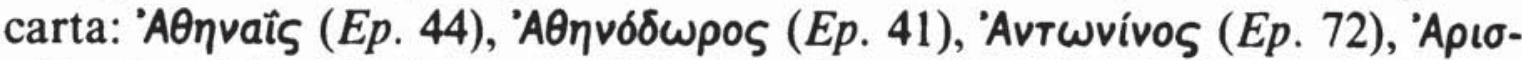

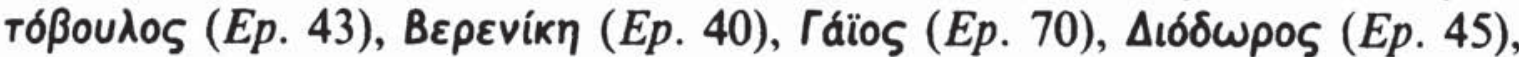

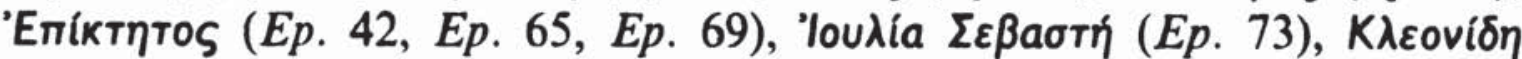

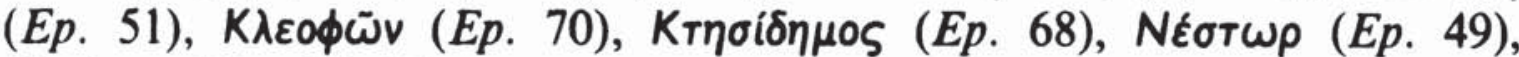

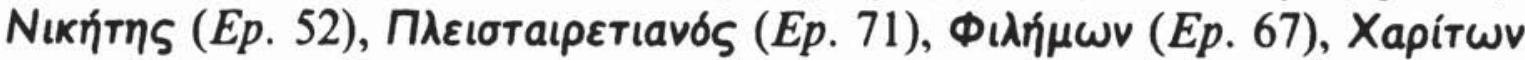
(Ep. 70).

\section{ARISTENeto}

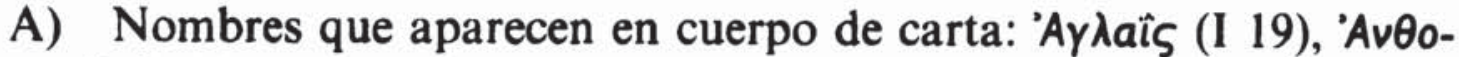

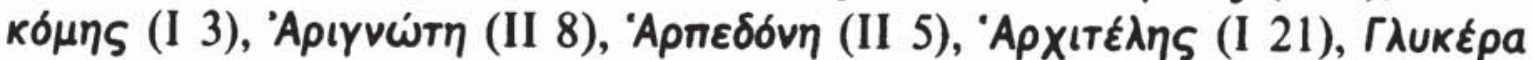

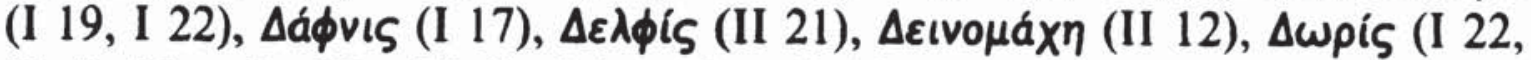

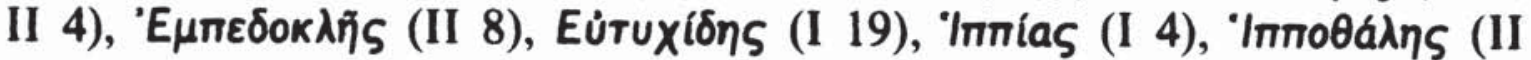

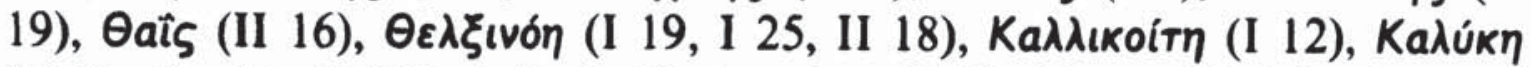

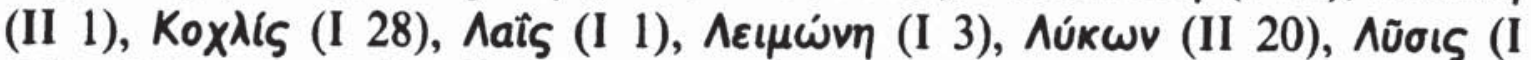

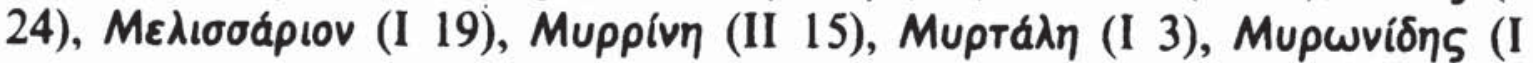

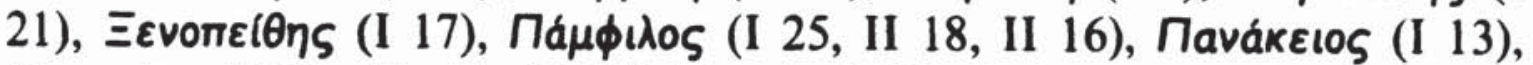

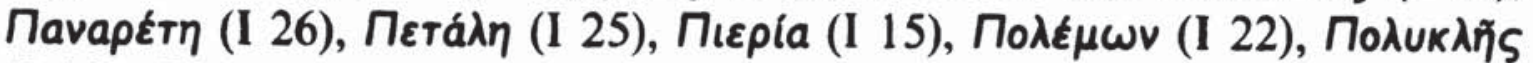

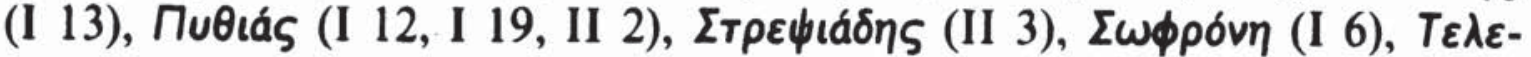

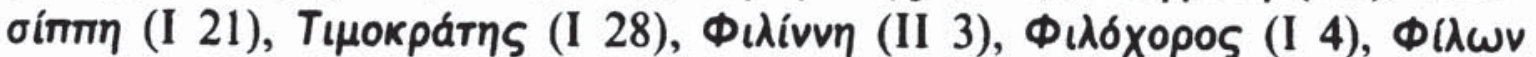

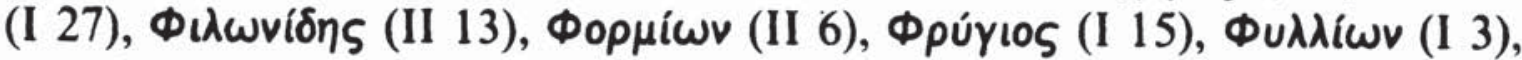

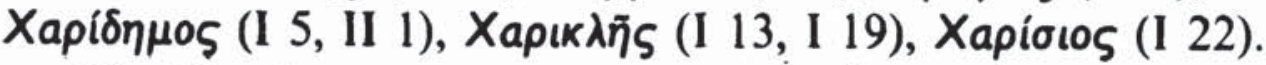

B) Nombres que aparecen en encabezamiento y no en cuerpo de

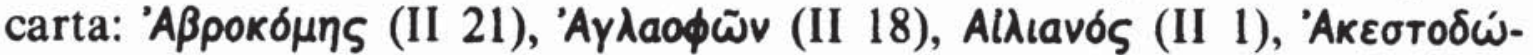

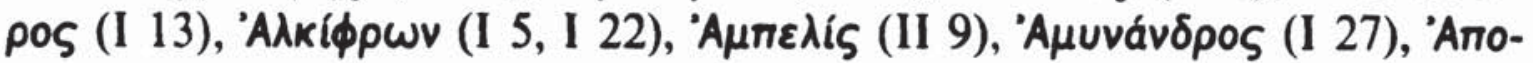




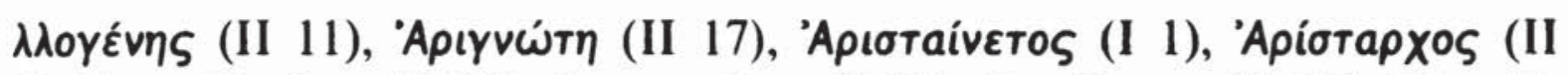

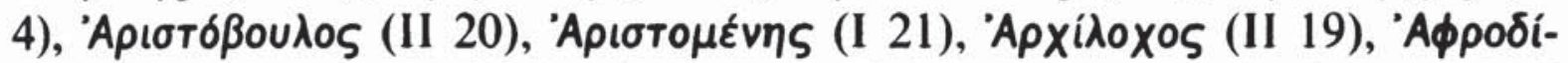

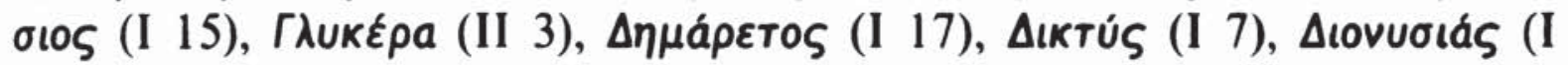

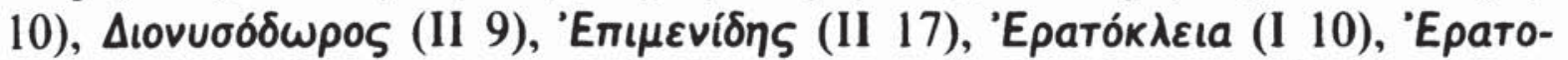

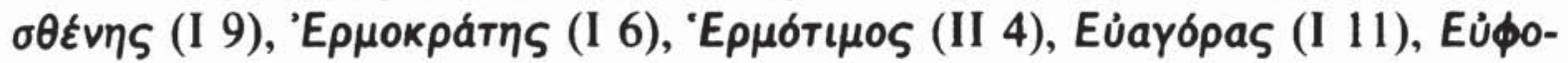

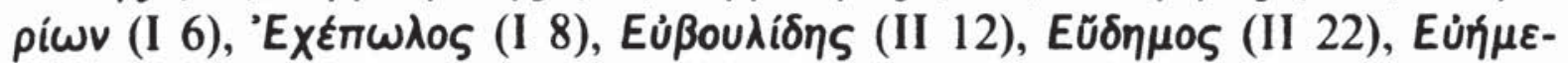

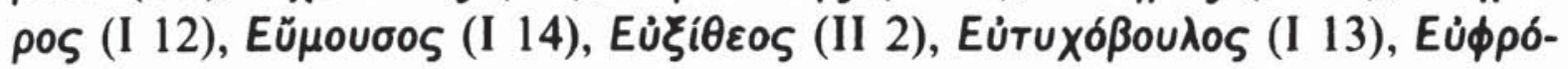

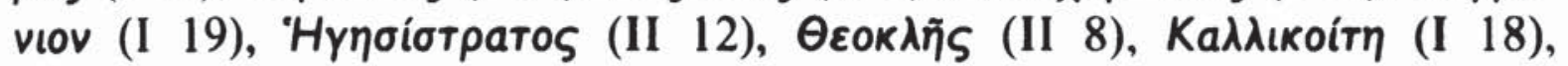

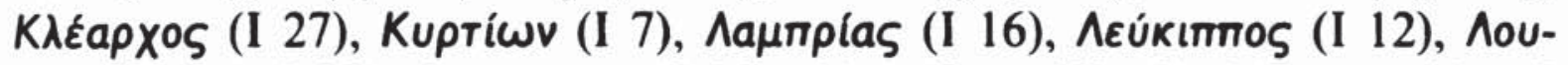

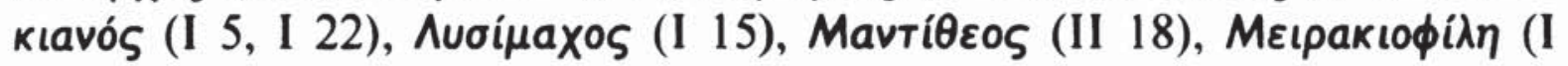

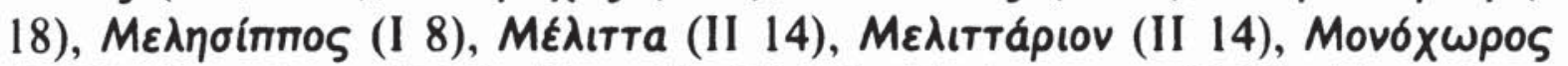

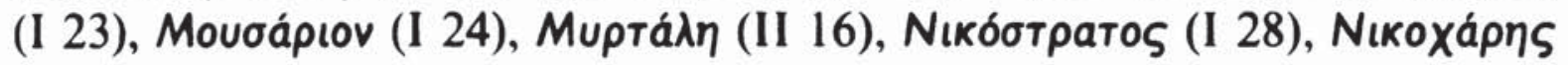

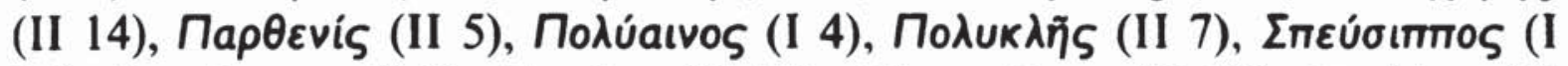

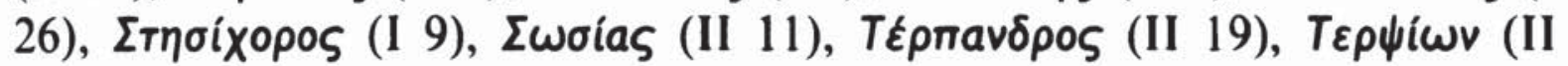

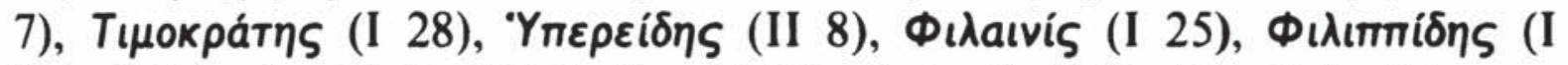

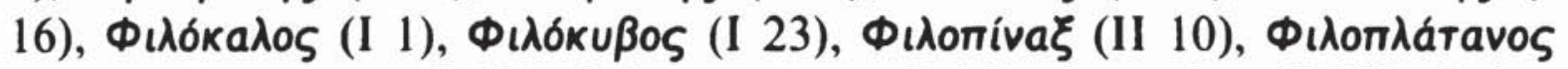

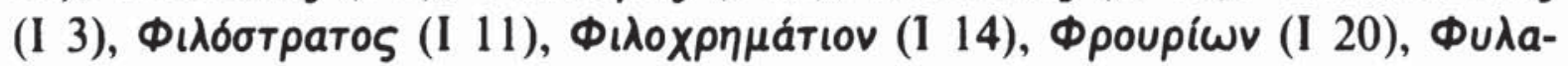

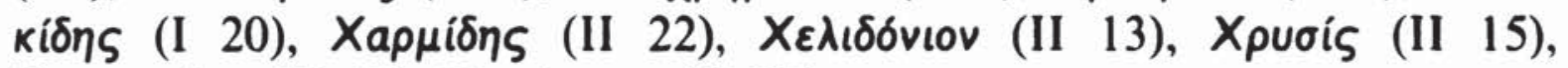

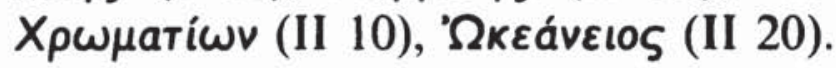

\section{Teofilacto}

A) Nombres que aparecen en cuerpo de carta: 'Aßpótovov (Ep. 51),

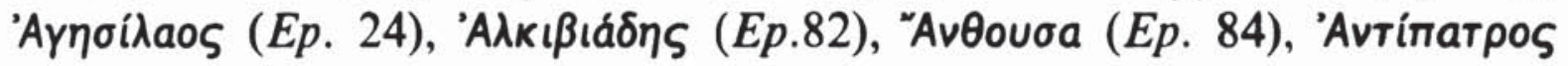

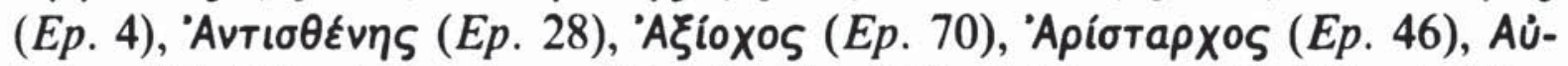

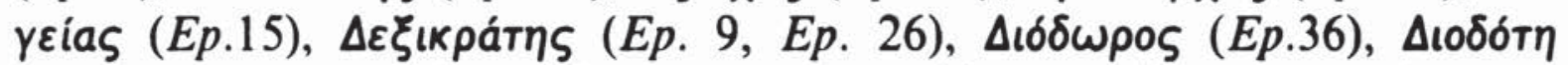

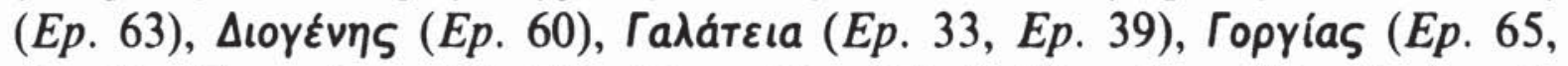

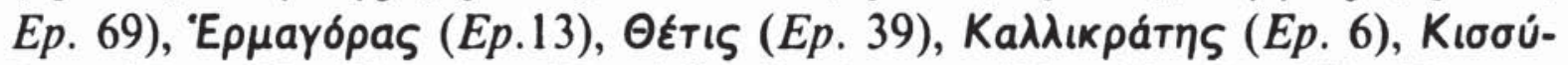

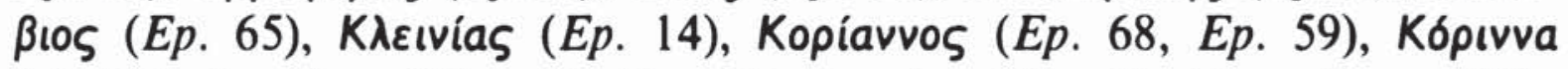

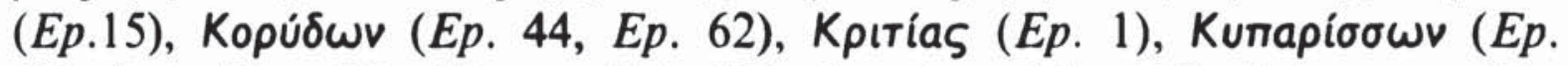

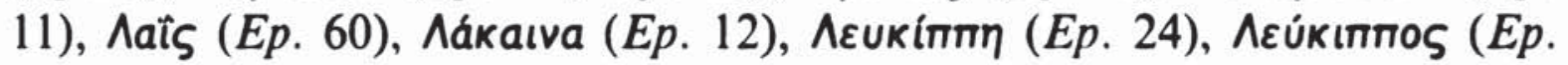

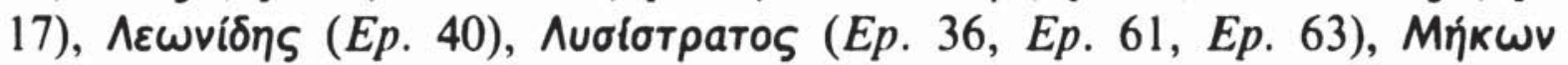

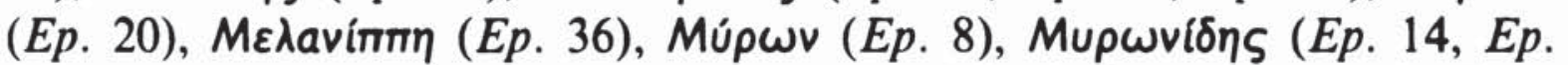

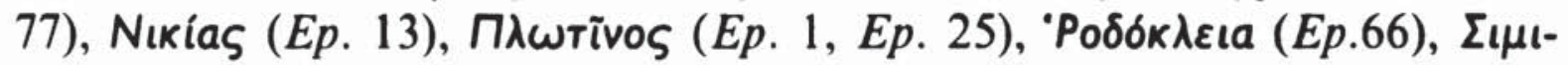

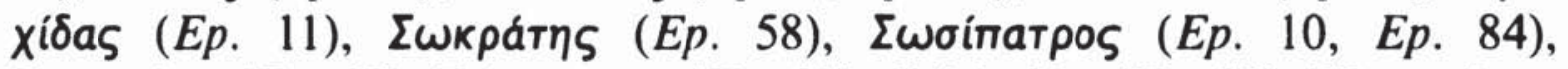

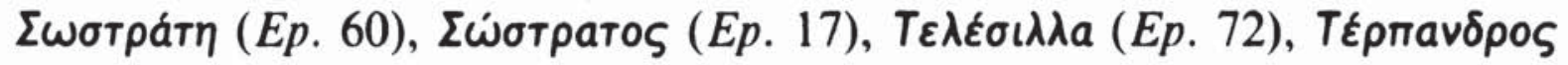

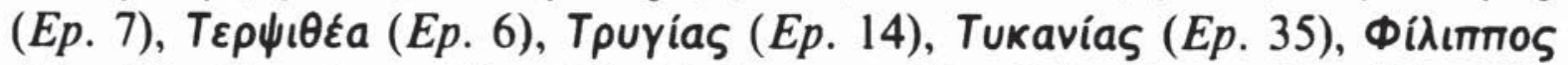

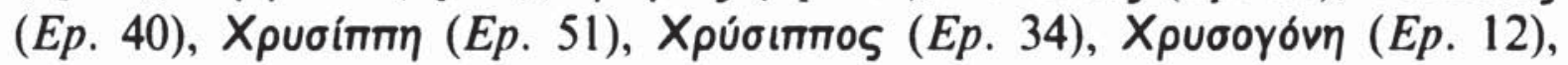

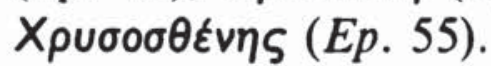

B) Nombres que aparecen en encabezamiento y no en cuerpo de

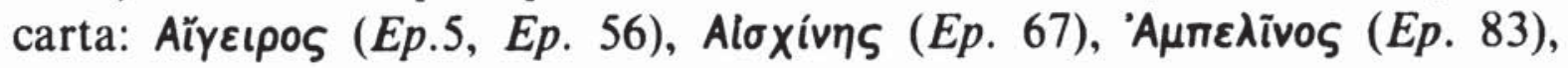




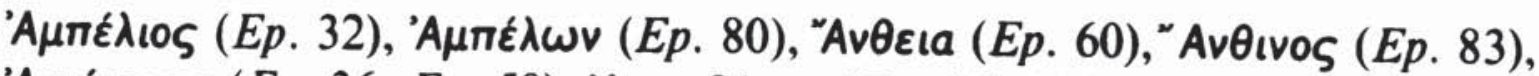

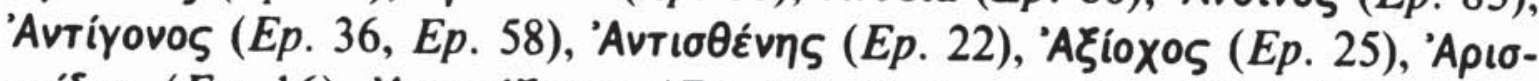

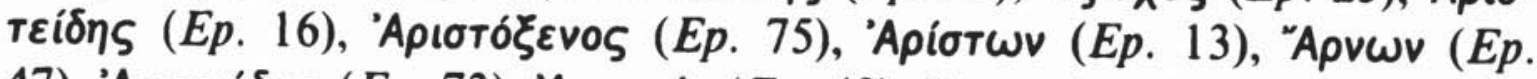

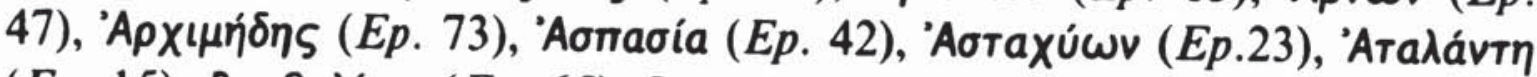

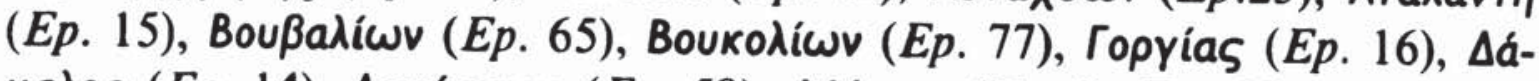

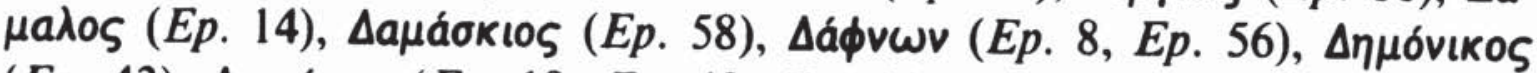

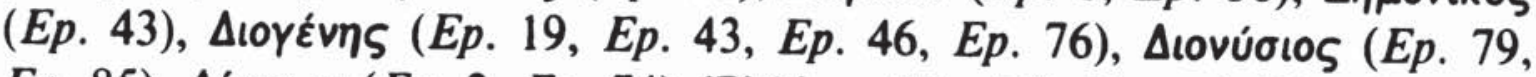

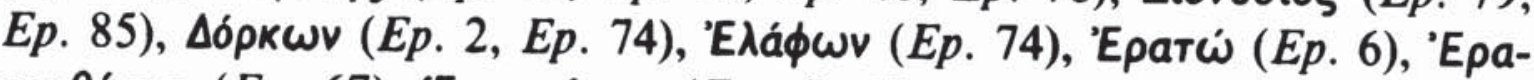

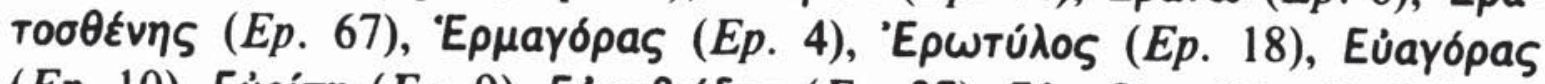

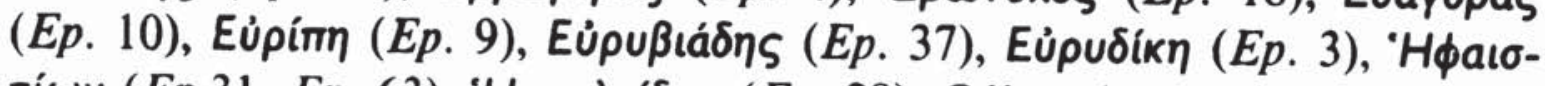

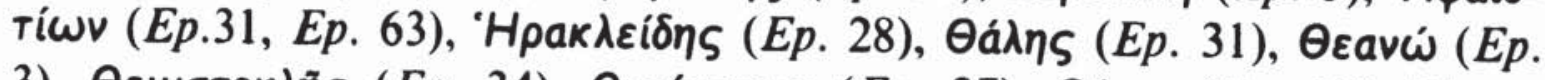

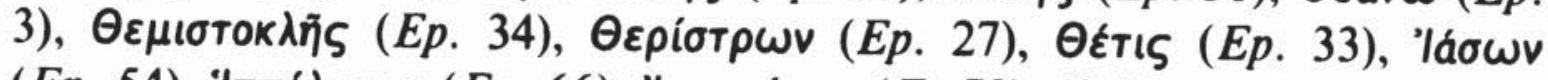

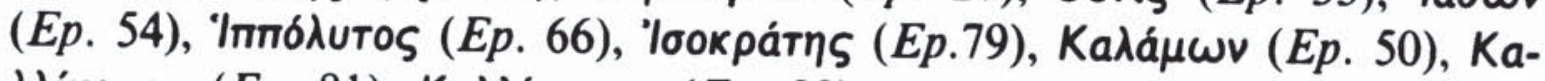

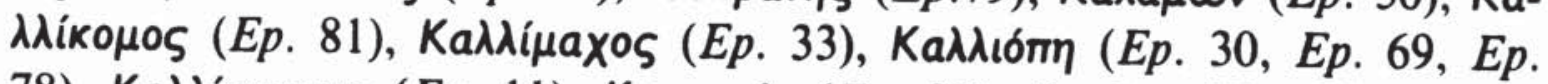

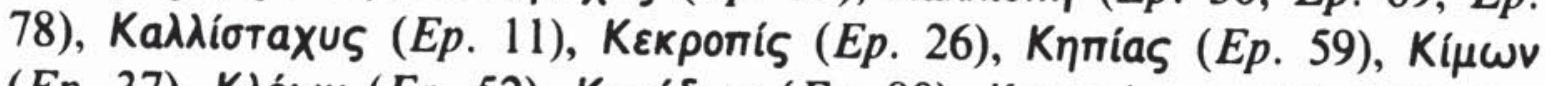

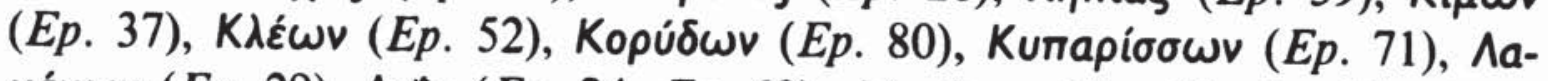

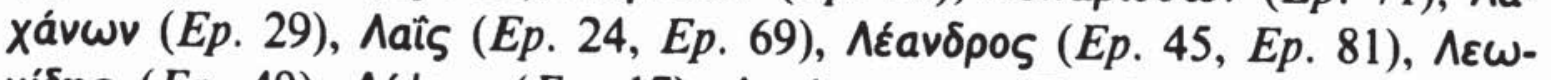

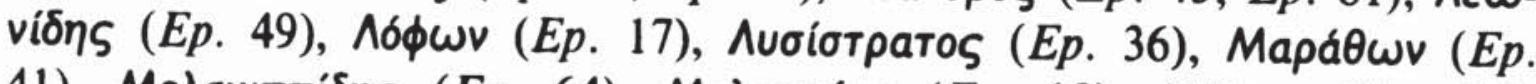

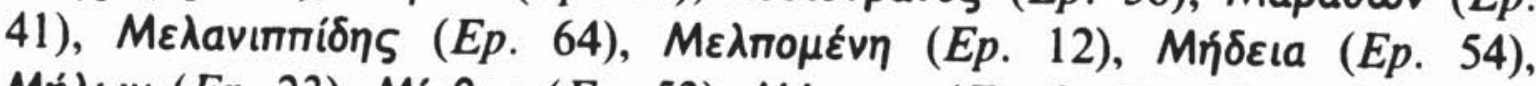

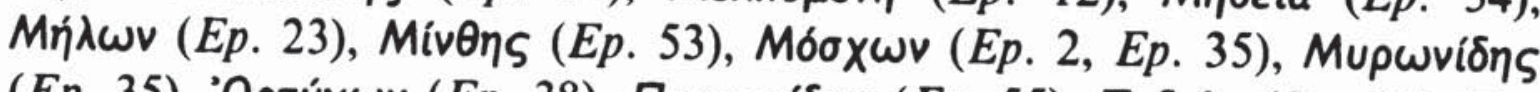

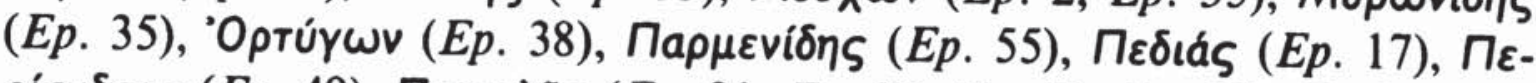

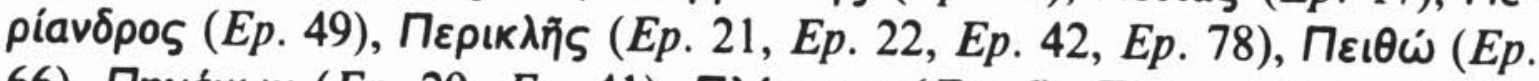

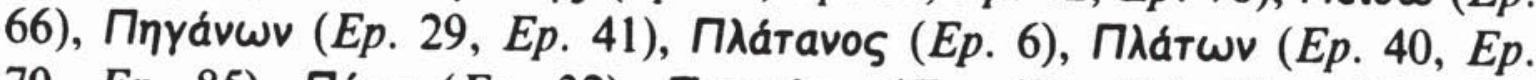

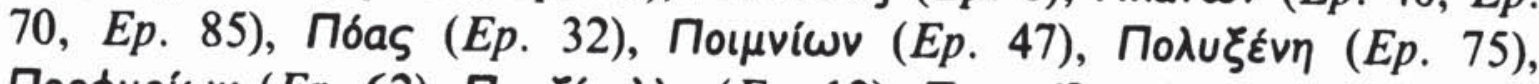

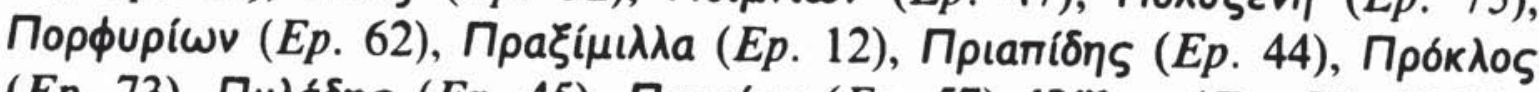

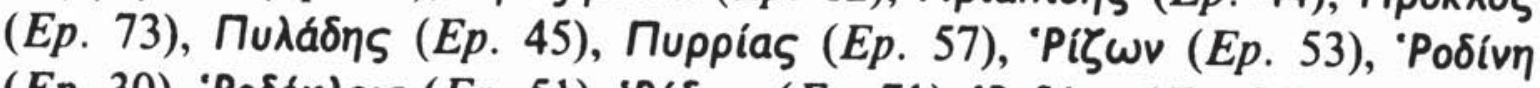

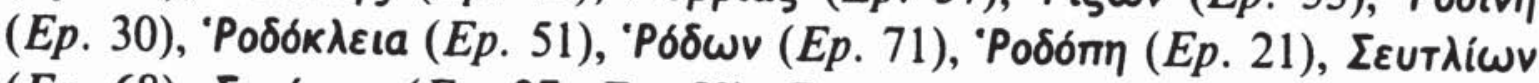

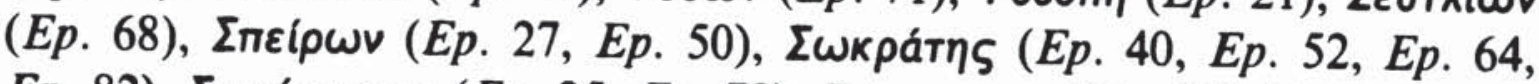

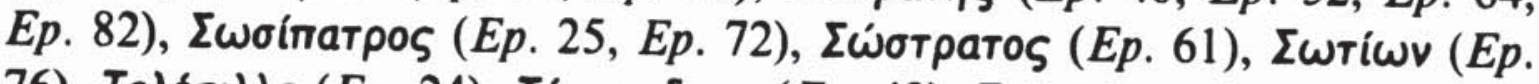

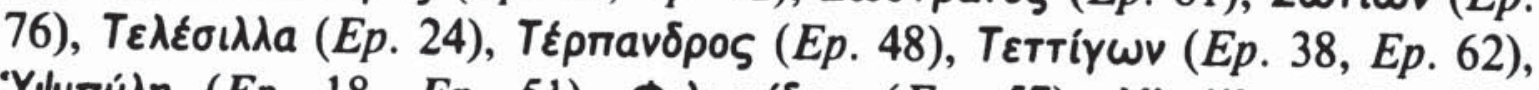

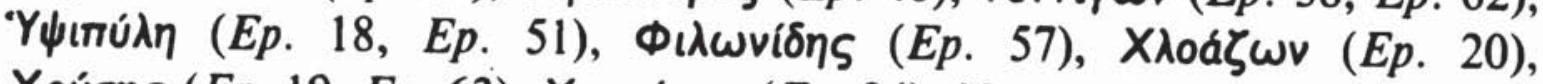

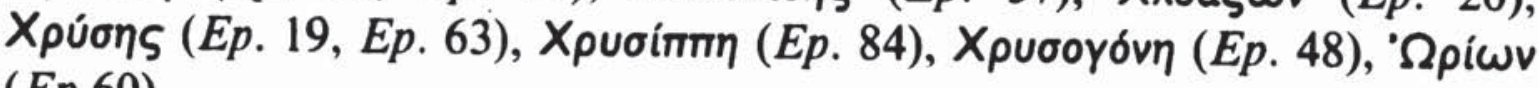
(Ep.60). 